\title{
Caspase-Activated DNase/DNA Fragmentation Factor 40 Mediates Apoptotic DNA Fragmentation in Transient Cerebral Ischemia and in Neuronal Cultures
}

\author{
Guodong Cao, ${ }^{1,3}$ Wei Pei, ${ }^{1,3}$ Jing Lan, ${ }^{1,3}$ R. Anne Stetler, ${ }^{1}$ Yumin Luo, ${ }^{1}$ Tetsuya Nagayama, ${ }^{1}$ \\ Steven H. Graham, ${ }^{1,5}$ Xiao-Ming Yin, ${ }^{3}$ Roger P. Simon, ${ }^{4}$ and Jun Chen ${ }^{1,3,5}$ \\ Departments of ${ }^{1}$ Neurology and ${ }^{2}$ Pathology and ${ }^{3}$ Pittsburgh Institute for Neurodegenerative Disorders, University of \\ Pittsburgh School of Medicine, Pittsburgh, Pennsylvania 15261, ${ }^{4}$ RS Dow Center for Neurobiology, Legacy Research, \\ Portland, Oregon 97208, and 5 Geriatric Research, Educational and Clinical Center, Veterans Affairs Pittsburgh Health \\ Care System, Pittsburgh, Pennsylvania 15261
}

Nuclear changes, including internucleosomal DNA fragmentation, are characteristic features of neuronal apoptosis resulting from transient cerebral ischemia and related brain insults for which the molecular mechanism has not been elucidated. Recent studies suggest that a caspase-3-mediated mechanism may be involved in the process of nuclear degradation in ischemic neurons. In this study, we cloned from rat brain a homolog cDNA encoding caspase-activated deoxyribonuclease (CAD)/ DNA fragmentation factor 40 (DFF40), a $40 \mathrm{kDa}$ nuclear enzyme that is activated by caspase-3 and promotes apoptotic DNA degradation. Subsequently, we investigated the role of CAD/ DFF40 in the induction of internucleosomal DNA fragmentation in the hippocampus in a rat model of transient global ischemia and in primary neuronal cultures under ischemia-like conditions. At 8-72 hr after ischemia, CAD/DFF40 mRNA and protein

Transient global cerebral ischemia results in selective and delayed neuronal death in the hippocampal CA1 region. Although the ultrastructural changes in ischemic CA1 neurons appear to be inconsistent with that of classical apoptosis (Colbourne et al., 1999), evidence has emerged suggesting the involvement of an active cell death component in this injury setting. Ischemic cell death of CA1 neurons is associated with the regulation of apoptosis-regulatory genes (Krajewski et al., 1995; Chen et al., 1996, 1997; Honkaniemi et al., 1996; Clemens et al., 1997; Dixon et al., 1997; Kinoshita et al., 1997), and forced overexpression of certain anti-apoptotic gene products markedly affects the outcome of ischemia in this region (Kitagawa et al., 1998; Xu et al., 1999). Among the endogenous gene products that may contribute to ischemic CA1 neuronal death, caspase- 3 may play a central role. There is strong evidence that caspase- 3 activation and subsequent proteolytic degradation of cellular substrates mediate neuronal death in injured CA1 (Gillardon et al., 1997; Chen et al.,

Received March 2, 2001; revised April 17, 2001; accepted April 18, 2001.

This work was supported by National Institutes of Health Grants NS38560 and NS36736 (to J.C.) and NS35965 (to J.C., S.H.G., and R.P.S.). J.C. and S.H.G. were also supported in part by the Geriatric Research, Education and Clinical Center, Veterans Affairs Pittsburgh Health Care System (Pittsburgh, PA). We thank Cristine O'Horo for technical assistance, Carol Culver for editorial assistance, and Pat Strickler for secretarial support.

Correspondence should be addressed to Dr. Jun Chen, Department of Neurology, S-507, Biomedical Science Tower, University of Pittsburgh School of Medicine, Pittsburgh, PA 15213. E-mail: jun@med.pitt.edu.

Copyright $\odot 2001$ Society for Neuroscience $0270-6474 / 01 / 214678-13 \$ 15.00 / 0$ were induced in the degenerating hippocampal CA1 neurons. CAD/DFF40 formed a heterodimeric complex in the nucleus with its natural inhibitor CAD (ICAD) and was activated after ischemia in a delayed manner ( $>24 \mathrm{hr}$ ) by caspase-3, which translocated into the nucleus and cleaved ICAD. Furthermore, an induced CAD/DFF40 activity was detected in nuclear extracts in both in vivo and in vitro models, and the DNA degradation activity of CAD/DFF40 was inhibited by purified ICAD protein. These results strongly suggest that CAD/DFF40 is the endogenous endonuclease that mediates caspase-3-dependent internucleosomal DNA degradation and related nuclear alterations in ischemic neurons.

Key words: cerebral ischemia; apoptosis; programmed cell death; caspase-3; DNA fragmentation; caspase-activated deoxyribonuclease

1998a; Himi et al., 1998; Ni et al., 1998; Gillardon et al., 1999; Ouyang et al., 1999; Xu et al., 1999). One important biochemical feature of ischemic CA1 neuronal death that is linked to caspase-3 activation appears to be the induction of DNA fragmentation. DNA fragmentation at the nucleosomal levels is a characteristic manifestation of apoptosis and constitutes a highly reproducible cell-death marker in the hippocampus after global ischemia (MacManus et al., 1993; Nitatori et al., 1995; Zhu et al., 1998; Ferrand-Drake and Wieloch, 1999). A strong linkage between caspase-3 activation and internucleosomal DNA fragmentation in neurons has been suggested by the observation that DNA fragmentation associated with ischemic or traumatic brain injury can be blocked by inhibiting caspase-3-like activity (Yakovlev et al., 1997; Chen et al., 1998a; Himi et al., 1998). Despite these findings, however, the precise mechanism leading to apoptotic DNA fragmentation after ischemia is poorly understood.

A specific caspase-3-activated DNase responsible for DNA fragmentation in mammalian cells has been identified and characterized (Liu et al., 1997; Enari et al., 1998; Sakahira et al., 1998). This DNase, designated as DNA fragmentation factor (DFF40) or caspase-activated deoxyribonuclease (CAD), is revolutionarily conserved crossing rodents and human (Enari et al., 1998; Mukae et al., 1998). CAD/DFF40 normally exists in the cell as a nonactive heterodimeric complex with its natural inhibitor, ICAD (DFF45 or DFF35). Caspase-3-mediated cleavage of ICAD allows CAD/DFF40 to be released from the CAD/ICAD complex and spontaneously activated (Chen et al., 2000). Acti- 
vated CAD/DFF40 then results in the degradation of genomic DNA into nucleosomal fragments, which constitutes an important mechanism underlying caspase-3-dependent apoptotic nuclear alterations (Sakahira et al., 1998).

Because apoptotic DNA fragmentation in the ischemic hippocampus is induced, at least in part, via caspase- 3 activation, we hypothesized that endogenous CAD/DFF40 may be activated after ischemia and mediate DNA degradation. To test this hypothesis, we cloned the rat brain homolog gene encoding CAD/ DFF40. Then we characterized the regional distribution and temporal profile of CAD/DFF40 gene expression and nuclear translocation in the hippocampus after transient global ischemia. Lastly, we determined whether endogenous CAD/DFF40 activity is induced in the hippocampus after ischemia or in neuronal cultures under ischemia-like conditions.

\section{MATERIALS AND METHODS}

Animal model of transient global ischemia. Male Sprague Dawley rats weighing 300-350 gm (Hilltop Lab Animals, Scottdale, PA) were induced with $4 \%$ isoflurane in a mixture of $66 \% \mathrm{~N}_{2} \mathrm{O}$ and $30 \% \mathrm{O}_{2}$ using a face mask. Then, rats were intubated and ventilated with $1.5 \%$ isoflurane in a mixture of $68.5 \% \mathrm{~N}_{2} \mathrm{O}$ and $30 \% \mathrm{O}_{2}$. Transient global ischemia (15 min) was induced using the four-vessel occlusion method as previously described (Chen et al., 1996). Blood pressure, blood gases, and blood glucose concentration were monitored and maintained in the normal range throughout the experiments. Rectal temperature was continually monitored and kept at $37-37.5^{\circ} \mathrm{C}$ using a heating pad and a temperatureregulated heating lamp. Brain temperature was monitored using a 29 ga thermocouple implanted in the left caudate putamen and kept at $35.8 \pm$ $0.2^{\circ} \mathrm{C}$ during ischemia and at $37-37.5^{\circ} \mathrm{C}$ thereafter. Electroencephalogram (EEG) was monitored in all animals to ensure isoelectricity within $10 \mathrm{sec}$ after the induction of ischemia. Sham operations were performed in additional animals using the same anesthesia and surgical exposure procedures, except that the arteries were not occluded.

In vivo drug administration. In selective experiments, rats were subjected to intracerebral ventricular infusion of the caspase-3/7 inhibitor $N$-benzyloxycarbonyl-Asp(Ome)-Glu(Ome)-Val-Asp-(Ome)-fluoromethylketone ( $z$-DEVD-fmk) using the procedure previously described (Chen et al., 1998a). Each animal received three ventricular infusions of $1.5 \mu \mathrm{g}$ each (in $2 \mu \mathrm{l}$ of diluted DMSO in mock CSF) or the same volume of vehicle over a 5 min time period at $30 \mathrm{~min}$ before and 2 and $24 \mathrm{hr}$ after $15 \mathrm{~min}$ of ischemia. $z$-DEVD-fmk at the indicated dose was found to significantly inhibit caspase-3 activity and protect CA1 neurons from delayed death after ischemia (Chen et al., 1998a).

\section{cDNA cloning of rat brain $C A D / D F F 40$}

Construction of an adaptor-ligated cDNA library. Cerebella were dissected from four 1-week-old male Sprague Dawley rats. Polyadenylated RNA was isolated using polyA-tract-1000 mRNA isolation system (Promega, Madison, WI) and used as templates for cDNA synthesis. A brain cDNA library was constructed using a Marathon cDNA amplification kit (Clontech, Palo Alto, CA) according to the manufacturer's instructions. Briefly, the first strand was retro-transcripted using the Marathon cDNA synthesis primer and avian myeloblastosis virus (AMV) reverse transcriptase. The second strand was synthesized using the second strand enzyme mixture containing DNA polymerase I, RNase H, and T4 DNA ligase. The resulting double-strand cDNA was blunted using T4 DNA polymerase and purified by phenol-chloroform-isoamyl alcohol and chloroform extraction. The Marathon cDNA adaptor was ligated to both ends of the double-strand cDNA using a T4 DNA ligase and then subjected to rapid amplification of cDNA $5^{\prime}$ and $3^{\prime}$ ends $\left(5^{\prime}-\right.$ and 3'-RACE).

Rapid amplification of cDNA ends. An 807 bp cDNA fragment encoding the rat brain homolog of CAD/DFF40 was first generated by reverse transcription-PCR on the basis of the conserved sequences in human and mouse CAD: 5' -CGGTTCCCGGCTGTGCCTGTAC-3' (sense) and 5'TTGTGTGTGGTCTTCTTGTGGCAG-3' (antisense). Based on the sequence of this cDNA fragment, 5'- and $3^{\prime}-\mathrm{RACE}$ primers and two nested primers were designed as follows: for $5^{\prime}$-RACE, 5'-GGTACTGAAGAGGATCCGGCTC-3' and 5' nested primer, 5'-GGGTCTCTGCAGTAATATTCTGGC-3'; for 3'-RACE, 5'-CCAGAATATTAC-
TGCAGAGACCC-3' and 3' nested primer, 5'-AGAGCCCGGATCCTCTTCAGTACC- $3^{\prime}$. The adapter-ligated double-stranded cDNAs served as templates for RACE. After the first round of PCR using adaptor primer 1 and $5^{\prime}$ - or $3^{\prime}$-R ACE primer, the resulting PCR product was used as a template for the second round of PCR using adaptor primer 2 and $5^{\prime}$ or $3^{\prime}$ nested primer. The 5'-RACE- and $3^{\prime}$-RACE-amplified fragments were subcloned into pGEM-T easy vector (Promega) and then sequenced on both strands (University of Pittsburgh Sequencing Facility). Then, the full-length cDNA of CAD/DFF40 was obtained using PCR, based on the obtained 5'- and 3'-end sequences.

In vitro transcription and translation. To confirm that the cDNA contains the full open reading frame, we performed in vitro transcription and translation to detect its protein product. The Kozak sequence was added to the full-length CAD/DFF40 cDNA before the start code using PCR, and then the PCR products were inserted into the SmaI-digested pBluescript SK+ plasmid in forward orientation (designated as pSK-CAD). Coupled transcription and translation of CAD/DFF40 was performed using the TNT in vitro transcription-translation kit (Promega) according to the manufacturer's instructions. In brief, $1 \mu \mathrm{g}$ of $X b a \mathrm{I}$ linearized pSK-CAD was incubated at $30^{\circ} \mathrm{C}$ for $2 \mathrm{hr}$ in $25 \mu \mathrm{l}$ of TNT reagent, $2 \mu \mathrm{l}$ of reaction buffer, $1 \mu \mathrm{l}$ of amino acid mix, and $50 \mu \mathrm{Ci}$ of ${ }^{35} \mathrm{~S}$-methionine (>800 Ci/mmol; PerkinElmer Life Sciences, Boston, MA). Reaction mixture $(5 \mu \mathrm{l})$ was electrophoresed on a $15 \%$ polyacrylamide gel, dried, and exposed to x-ray film (Eastman Kodak, Rochester, NY) with intensifying screens. In a separate reaction, ${ }^{35} \mathrm{~S}$-methionine was replaced by cold methionine, and the reaction product was electrophoresed and subjected to Western blot analysis using an affinity-purified rabbit polyclonal anti-CAD antibody at a dilution of 1:1000.

cDNA transfection. To determine whether the cloned cDNA encodes a functional DNase, CAD/DFF40 cDNA was transfected into human 293 cells, and DNA degradation was evaluated after the cells were exposed to the apoptosis inducer Staurosporin. This cell line normally contains little CAD/DFF40 and thus is retarded to develop apoptotic DNA fragmentation (Mukae et al., 1998). In the present study, plasmid transfection was performed using the lipofectamine PLUS kit according to the manufacturer's protocol (Life Technologies, Grand Island, NY). Four sets of plasmids were transfected, including the empty pcDNA3.1 vector, pcDNA3.1 vector containing CAD/DFF40 cDNA inserts, pcDNA3.1 vector containing rat ICAD cDNA inserts, and pcDNA3.1 vector containing both CAD/DFF40 and ICAD inserts. Twenty-four hours later, the cells were incubated in $1 \mu \mathrm{M}$ Staurosporin for $6 \mathrm{hr}$, collected, and washed with ice-cold PBS. The soluble DNA fragments were isolated using a previously described method (Herrmann et al., 1994) with slight modifications. Briefly, $1 \times 10^{7}$ cells were washed twice with ice-cold PBS and centrifuged at $500 \times g$ for $5 \mathrm{~min}$. The pellet was resuspended in 100 $\mu \mathrm{l}$ of lysis buffer containing $50 \mathrm{~mm}$ Tris- $\mathrm{HCl}, \mathrm{pH}$ 7.5, 20 mm EDTA, $\mathrm{pH}$ 8.0, and $1 \% \mathrm{NP}-40$; incubated on ice for $10 \mathrm{~min}$; and then centrifuged at $13,000 \mathrm{rpm}$ for $5 \mathrm{~min}$. The supernatant was digested with RNaseA $(0.5$ $\mu \mathrm{g} / \mu \mathrm{l})$ at $50^{\circ} \mathrm{C}$ for $2 \mathrm{hr}$, then digested with proteinase $\mathrm{K}(0.5 \mu \mathrm{g} / \mu \mathrm{l})$ and $1 \% \mathrm{SDS}$ at $55^{\circ} \mathrm{C}$ for $2 \mathrm{hr}$. The DNA fragments were recovered using the Wizard Plus Minipreps DNA Purification System (Promega). The eluted DNA $(20 \mu \mathrm{l})$ was electrophoresed on $1.2 \%$ agarose gel and visualized under UV light.

\section{Northern blot analysis}

Total RNA was prepared from rat tissues using the RNAgent total RNA isolation system (Promega) according to the manufacturer's instructions. RNA from the following four sets of tissues was analyzed: set 1, various organ tissues from adult male rat, including the heart, liver, spleen, lung, kidney, whole brain, intestine, stomach, testis, and skeletal muscle; set 2, various regions from the adult rat brain, including the cortex, cerebellum, hippocampus, thalamus, and caudate putamen; set 3 , cerebella of rat brains at different ages, including embryonic day 17 and postnatal weeks 1,2 , and 12 (adult); set 4, hippocampi of adult brains subjected to $15 \mathrm{~min}$ of global ischemia followed by 8,24 , or $72 \mathrm{hr}$ of reperfusion.

Total RNA $(30 \mu \mathrm{g})$ was electrophoresed on a $1 \%$ agarose-formaldehyde gel, blotted onto a zeta-probe GT nylon membrane (Bio-Rad, Hercules, CA), and prehybridized for $6 \mathrm{hr}$ at $42^{\circ} \mathrm{C}$. The full-length CAD/DFF40 cDNA was labeled with ${ }^{32} \mathrm{P}$ using a random primer labeling kit (Boehringer Mannheim, Indianapolis, IN), and the labeled cDNA was purified using the G-25 spin columns. The membranes were subsequently hybridized with the labeled cDNA probe $\left(4 \times 10^{6} \mathrm{cpm} / \mathrm{ml}\right)$ overnight at $42^{\circ} \mathrm{C}$ as previously described (Chen et al., 1998a). To control for sample loading, the membranes containing the original probe were stripped and rehybridized with a ${ }^{32} \mathrm{P}$-labeled glyceraldehyde-3-phosphate- 
dehydrogenase (GAPDH) probe. All densitometric values for CAD/ DFF40 were normalized to the value for GAPDH that was determined on the same lane.

\section{In situ hybridization}

Rats that were used for in situ hybridization were anesthetized with $8 \%$ chloral hydrate and decapitated at 4, 8, 24, and $72 \mathrm{hr}$ after $15 \mathrm{~min}$ of global ischemia or $24 \mathrm{hr}$ after sham operation ( $n=4$ per group). Frozen coronal sections $\left(15 \mu \mathrm{m}\right.$ thick) were cut on a cryostat at $-20^{\circ} \mathrm{C}$ and collected on precleaned Probe-on-Slides (Fisher Scientific, Pittsburgh, PA). Sections at the levels of the dorsal hippocampus (anteroposterior, -3.5 to $-4.0 \mathrm{~mm}$ from the bregma) from ischemic, sham-operated, or naïve control brains were prepared for in situ hybridization. The ${ }^{35} \mathrm{~S}$ labeled single-strand RNA probe was prepared from pBluescript SK+ plasmid containing the rat brain CAD/DFF40 cDNA inserts (300 bp) in both the sense and antisense orientation using the same procedures as previously described (Chen et al., 1998b). The sections were hybridized with the labeled RNA probe $\left(1 \times 10^{7} \mathrm{cpm} / \mathrm{ml}\right)$ in a hybridization mixture for $18 \mathrm{hr}$ at $55^{\circ} \mathrm{C}$. After the washing procedures, the slides were dehydrated, air-dried, and exposed to a Kodak film for 3 weeks. Then, relative changes in mRNA expression were quantified by determining the ratio of the optical density of the specified regions in ischemic brains versus controls using the MCID system (Chen et al., 1998b). Cellular localization of the labeled mRNA was evaluated by coating slides with Kodak NTB-2 emulsion.

\section{Western blot analysis}

Animals were killed at 4, 8, 24, or $72 \mathrm{hr}$ after $15 \mathrm{~min}$ of ischemia or 24 hr after sham operation ( $n=4$ per experimental condition). A portion of the hippocampus containing the CA1 sector or CA3 and dentate gyrus was separately dissected for protein extraction. The tissues were first homogenized in a hypotonic buffer containing (in $\mathrm{mm}$ ): 50 Tris- $\mathrm{HCl}, \mathrm{pH}$ 8.0, $25 \mathrm{MgCl}_{2}$, and 0.1 phenylmethylsulfonyl fluoride, using a Dounce homogenizer, and kept on ice for $15 \mathrm{~min}$; the nuclear and cytosolic fractions of protein were separately isolated by centrifugation as previously described (Wood and Earnshaw, 1990; Liu et al., 1996; Chen et al., 2000) and subjected to Western blot analysis using standard methods. The antibody used to detect CAD/DFF40 is an affinity-purified rabbit polyclonal antibody against a C-terminal sequence of rat CAD/DFF40. The antibody to detect ICAD is a custom-made affinity-purified rabbit polyclonal antibody raised against rat ICAD that recognized both the intact and the larger cleavage form of ICAD (Chen et al., 2000). The working dilutions for CAD/DFF40 and ICAD antibodies in the present study were 1:1000 and 1:2000, respectively. For the detection of caspase-3, a polyclonal antibody recognizing the active form (p17) of caspase- 3 was used at the dilution of 1:500. The specificity of the immunoreactivity for each antibody was confirmed by either preabsorption experiments (for ICAD and caspase-3) or omitting the primary antibodies from the reaction mixture (for CAD/DFF40). Immunoreactivity signals were quantified by densitometry measurement (Chen et al., 1998a).

\section{Immunohistochemistry}

Animals were anesthetized with $8 \%$ chloral hydrate at 4, 8, 24, or $72 \mathrm{hr}$ after $15 \mathrm{~min}$ of ischemia or $24 \mathrm{hr}$ after sham operation $(n=4$ per time point). They were perfused with $200 \mathrm{ml}$ of heparinized $0.9 \%$ saline followed by $500 \mathrm{ml}$ of $4 \%$ paraformaldehyde in $0.1 \mathrm{M} \mathrm{PBS,} \mathrm{pH}$ 7.4. The brains were removed and processed for paraffin embedding and cutting, and coronal sections at the levels of dorsal hippocampus were selected for immunohistochemical staining. The procedures for immunohistochemistry were the same as previously described (Chen et al., 1998a). Immunohistochemical staining for CAD/DFF40 (working dilution, 1:250) and caspase-3 (working dilution, 1:500) were performed using the same antibodies used for Western blot analysis. For double-label immunofluorescence staining of CAD/DFF40 and caspase-3, sections were first incubated with the anti-caspase-3 antibody, followed by incubation for 1 $\mathrm{hr}$ at room temperature with goat anti-rabbit $\mathrm{Cy} 3.18$ immunoconjugate (Jackson ImmunoResearch, West Grove, PA) at 1:2500 dilutions. Sections were washed three times in PBS for 15 min each and then subjected to CAD/DFF40 immunostaining followed by secondary antibody incubation (goat anti-rabbit biotin-immunoconjugate, 1:3000). After three PBS washes, the sections were incubated at room temperature for $15 \mathrm{~min}$ in fluorescein-avidin D (cell sorting grade; Vector Laboratories, Burlingame, CA) at $8 \mu \mathrm{g} / \mathrm{ml}$. The sections were washed four times in PBS, mounted in gelvatol, and coverslipped. For the assessment of nonspecific staining, alternating sections from each experimental condition were incubated without the primary antibody.

\section{Production of caspase-resistant ICAD fusion protein}

A cDNA encoding the whole reading frame of rat brain ICAD was isolated from a rat brain cDNA library (GenBank accession number AF136601) and subsequently subcloned into the pSPORT1 vector (Life Technologies). To generate caspase-resistant ICAD fusion protein, sitedirected mutagenesis was performed using the Gene Editor system (Promega) to mutate the two aspartic acid residues (117 and 224) known to be the caspase cleavage sites (Chen et al., 2000). The mutations were confirmed by DNA sequencing.

To generate fusion protein, the D117E and D224E double mutations of ICAD $\left(\mathrm{ICAD}_{\mathrm{dm}}\right)$ cDNA were amplified using the primers 5'-GCC GCC ACC ATG GAG CTG TCG CGG GGA GCC AGC-3' (sense) and 5'-CTA GTT CTT GCC CAC CTC TAA ATC C-3' (antisense). The cDNA was fused into the glutathione $S$-transferase (GST) gene in PGEX-2T vector, according to the manufacturer's instructions (Amersham Pharmacia Biotech, Piscataway, NJ). The GST-ICAD fusion protein was expressed in Escherichia coli BL21 cells and absorbed to glutathione-Sepharose 4B column. Then, the fusion proteins were cleaved by thrombin for $16 \mathrm{hr}$ at room temperature to remove the GST portion. The elute was collected by centrifugation at $500 \times g$ for $5 \mathrm{~min}$ at $4^{\circ} \mathrm{C}$. The purified ICAD protein was verified by Western blot analysis.

\section{Detection of nuclear CAD/DFF40 activity}

This assay measures the ICAD-inhibitable DNase activity (CAD/DFF40 activity) in cellular protein extracts under apoptotic conditions (Liu et al., 1997; Enari et al., 1998; Sakahira et al., 1998; Chen et al., 2000). To determine whether CAD/DFF40 activity was induced in the brain after ischemia, rats were decapitated at 8,24 , and $72 \mathrm{hr}$ after $15 \mathrm{~min}$ of global ischemia or $24 \mathrm{hr}$ after sham operation (8 rats per experimental condition). The hippocampi were isolated, and the portion containing the CA1 region was dissected. Nuclear protein was extracted as described above. To perform the assay, protein extracts $(100 \mu \mathrm{g})$ were incubated with genomic DNA isolated from normal brain cells $\left(5 \times 10^{5}\right.$ per reaction) (Chen et al., 2000) overnight at $32^{\circ} \mathrm{C}$ in the reaction buffer containing (in mM): $50 \mathrm{NaCl}, 10$ HEPES, pH 7.0, $40 \beta$-glycerophosphate, $2 \mathrm{MgCl}_{2}, 5$ EGTA, 1 DTT, and supplemented with an ATP-regeneration system containing $2 \mathrm{~mm}$ ATP, $10 \mathrm{~mm}$ creatine phosphate, and $50 \mu \mathrm{g} / \mathrm{ml}$ creatine kinase (Liu et al., 1997). The reaction was terminated by adding the buffer containing $50 \mathrm{~mm}$ Tris-HCl, $\mathrm{pH}$ 8.0, $10 \mathrm{~mm}$ EDTA, protease $\mathrm{K}(0.5$ $\mathrm{mg} / \mathrm{ml})$, and RNase $(5 \mu \mathrm{g} / \mathrm{ml})$ and incubated at $50^{\circ} \mathrm{C}$ for $1 \mathrm{hr}$. The DNA was extracted with two changes of chloroform-isoamyl alcohol $(24: 1, \mathrm{v} / \mathrm{v})$ and then centrifuged for $20 \mathrm{~min}$ at $10,000 \times \mathrm{g}$. The samples were added to $1 / 15 \mathrm{vol}$ of $3 \mathrm{M}$ sodium acetate, $\mathrm{pH} 7.0$, and 2 vol of $95 \%$ cold ethanol to precipitate DNA at $-20^{\circ} \mathrm{C}$ overnight. The samples were spun at $13,000 \times g$ for $30 \mathrm{~min}$, and then the pellet was air-dried, washed in $70 \%$ ethanol, and resuspended in TE buffer (10 mM Tris, $1 \mathrm{~mm}$ EDTA, pH 7.4). DNA samples $(5 \mu \mathrm{g})$ were incubated in $50 \mu \mathrm{l}$ of terminal deoxynucleotidyl transferase (TdT) buffer containing $15 \mu \mathrm{Ci}$ of $\alpha^{-{ }^{32} \mathrm{P}-}$ dideoxyATP and $30 \mathrm{U}$ of TdT for $2 \mathrm{hr}$ at $27^{\circ} \mathrm{C}$. The reaction was stopped by the addition of $2 \mu \mathrm{l}$ of $0.5 \mathrm{~m}$ EDTA. The DNA was precipitated, electrophoresed on an agorose gel, and autoradiographed onto X-Omat RP-5 x-ray film (Eastman Kodak).

The in vitro apoptosis assay for morphology analysis was also performed to determine the effect of induced CAD/DFF40 activity on nuclear changes (Chen et al., 2000). This was done by incubating neuronal nuclei $\left(3 \times 10^{5}\right.$ per reaction) overnight at $37^{\circ} \mathrm{C}$ with nuclear protein extracts $(100 \mu \mathrm{g})$ prepared from ischemic samples. The nuclei were stained with propidium iodine, and the morphology was evaluated under a fluorescent microscope equipped with an image analysis system.

Two methods were used to determine the specific CAD/DFF40 activity with the above assays. In the first, purified caspase-resistant rat ICAD fusion protein $(0.2-1 \mu \mathrm{g} / \mathrm{ml})$ was added at the beginning of reactions to test whether the DNase activity present in the nuclear extracts could be inhibited. In the second, the nuclear extracts were immunoprecipitated using the anti-CAD/DFF40 antibody to deplete the endogenous CAD/ DFF40 protein before the activity assays.

\section{In vitro model of ischemia}

Primary cultures of cortical neurons were prepared from 16- to 17-d-old Sprague Dawley rat embryos as previously described (Nagayama et al., 1999). In brief, the cortical tissue was cut with a scalpel blade into $\sim 1$ $\mathrm{mm}^{3}$ pieces and incubated at $37^{\circ} \mathrm{C}$ for $30 \mathrm{~min}$ in $\mathrm{Ca}^{2+}$ and $\mathrm{Mg}^{2+}$-free 
Eagle's balanced salt solution containing $0.01 \%$ trypsin (1:250). Horse serum $(10 \%)$ was added then, and the tissue was triturated with a $5 \mathrm{ml}$ pipette. Cells were centrifuged for $10 \mathrm{~min}$ at $190 \times g$ and resuspended in Eagle's minimal essential medium prepared without glutamine, with twice the usual concentration of other amino acids and four times the usual concentration of vitamins (MEM-Pak; University of California, San Francisco Cell Culture Facility, San Francisco, CA). The culture was supplemented on the day of plating with $2 \mathrm{~mm}$ glutamine, $15 \mathrm{~mm}$ HEPES,

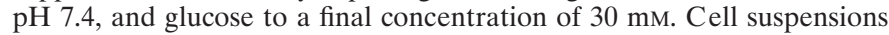
were filtered through a $7 \mu \mathrm{m}$ Falcon nylon cell drainer, supplemented with $10 \%$ horse serum and $10 \%$ fetal calf serum, and seeded at $3 \times 10^{5}$ cells per well on 24 -well Corning cell culture dishes, or at $1.25 \times 10^{7}$ per dish on $6 \mathrm{~cm}$ dishes coated with $100 \mu \mathrm{g} / \mathrm{ml}$ of poly-D-lysine. Cytosine arabinoside (AraC; $10 \mu \mathrm{M}$ ) was added on the fifth day in vitro (DIV). At $6 \mathrm{DIV}$, one-half of the medium was replaced with AraC-free medium, and one-third of the medium was replaced with fresh medium twice weekly thereafter. Experiments were conducted at 17 DIV, when cultures consisted primarily of neurons (94.3 $\pm 1.2 \%$ MAP2immunoreactive cells, $4 \pm 1 \%$ GFAP-immunoreactive cells; $n=10$ ).

To model ischemia-like conditions in vitro, primary cortical neuronal cultures were exposed to oxygen-glucose deprivation (OGD) (Nagayama et al., 1999) with modifications. Two-thirds of the culture medium was replaced four times with serum- and glucose-free medium, resulting in a final glucose concentration of $<1 \mathrm{~mm}$. The glucose-deprived cultures were then placed in a Billups-Rothenberg modular incubator chamber (Del Mar, San Diego, CA), which was flushed for 5 min with $95 \%$ argon and $5 \% \mathrm{CO}_{2}$ and then sealed. The chamber was placed in a waterjacketed incubator (Forma) at $37^{\circ} \mathrm{C}$ for $90 \mathrm{~min}$ and then returned to $95 \%$ air, $5 \% \mathrm{CO}_{2}$, and glucose-containing medium for a period of time indicated in each experiment. Control glucose-containing cultures were incubated for the same period of time at $37^{\circ} \mathrm{C}$ in humidified $95 \%$ air and $5 \% \mathrm{CO}_{2}$. To study apoptotic DNA fragmentation in primary neurons, OGD was induced in the presence of 1-10 nM MK801 to block the necrotic component of cell death.

\section{Statistical analysis}

Results are reported as mean values \pm SEM. The significance of difference between means was assessed by Student's $t$ test (single comparisons) or by ANOVA and post hoc Scheffe's tests, with $p<0.05$ considered statistically significant.

\section{RESULTS}

\section{cDNA cloning of rat brain CAD/DFF40}

To characterize the expression pattern and determine the functional role of CAD/DFF40 in the brain after ischemia, we cloned a cDNA containing the entire open reading frame of CAD/ DFF40 from a cDNA library constructed from 1-week-old rat cerebellum. Sequence analysis revealed that this cDNA encodes 349 amino acids (Fig. 1a). The deduced amino acid sequence showed 73 and $94 \%$ identity to the published sequences of human and mouse CAD/DFF40 (Enari et al., 1998; Mukae et al., 1998), respectively. The rat $\mathrm{CAD} / \mathrm{DFF} 40$ contains a stretch of 20 amino acids at the $\mathrm{C}$ terminus consisting of repetitive glutamine, proline, arginine, and lysine, strongly suggestive of a nuclear localization segment (Boulikas, 1993). In addition, the rat CAD/DFF40 is rich in cysteine (14 residues); notably, 8 cysteine residues are localized in the 80 amino acid $\mathrm{N}$ terminus, which have been implied as participants in the heterodimerization between CAD/DFF40 and ICAD (Mukae et al., 1998).

Using the cloned cDNA as a template, the in vitro transcription-translation assay produced a protein at $\sim 40 \mathrm{kDa}$ (data not shown), the predicted size for CAD/DFF40, thus confirming the validity of the sequence of rat CAD/DFF40 cDNA.

Transfection of the rat CAD/DFF40 cDNA in human 293 cells markedly promoted internucleosomal DNA fragmentation in response to the caspase-3 and apoptosis inducer staurosporin (STS) (Fig. 1b). This cell line normally contains extremely low basal levels of CAD/DFF40 and thus is retarded to develop caspasedependent DNA fragmentation during apoptosis (Mukae et al.,

\section{d}

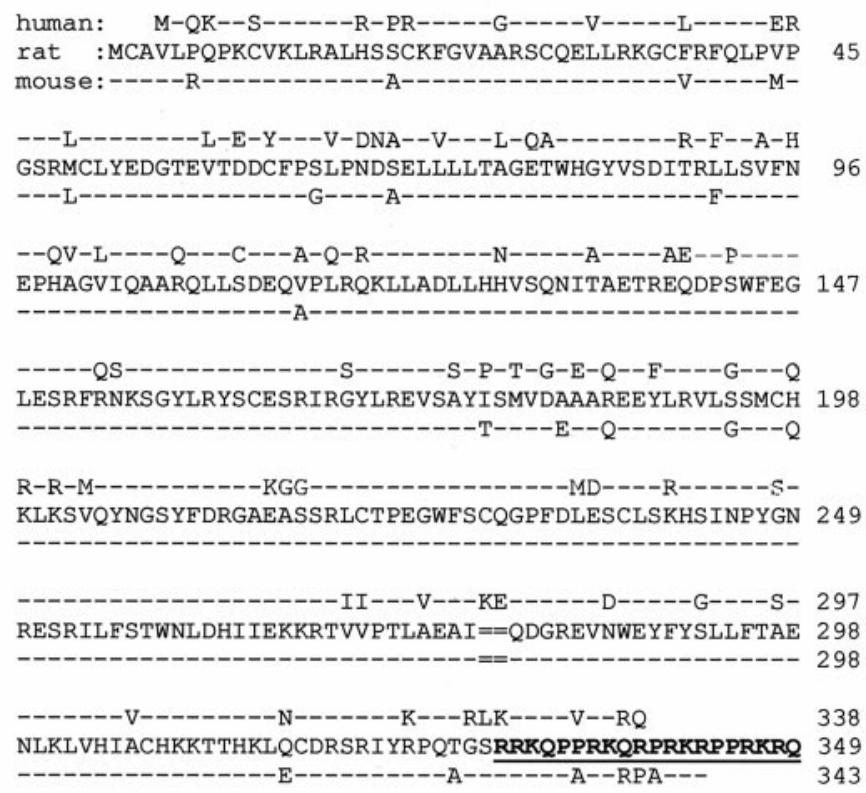

b

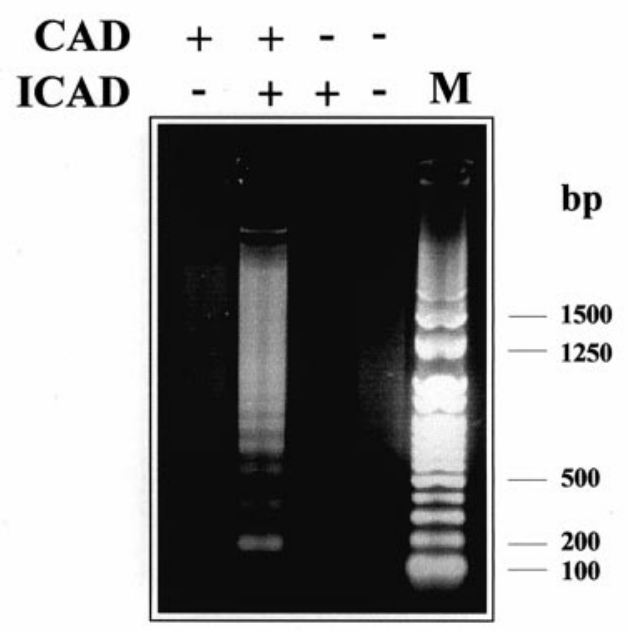

Figure 1. Cloning of rat CAD/DFF40. $a$, Deduced amino acid sequence of rat CAD/DFF40 (GenBank accession number AF 136598) and comparison of amino acid sequences among rat, mouse (GenBank accession number AB 009377), and human DFF40 (GenBank accession number AB 013918). Identical amino acids are presented as dashes. The rat sequence contains a nuclear localization segment at its $\mathrm{C}$ terminus (bold and underlined). $b$, Cotransfection of rat $\mathrm{CAD} / \mathrm{DFF} 40$ and ICAD, but not CAD/DFF40 or ICAD alone, enhances STS-induced internucleosomal DNA fragmentation in human 293 cells. DNA extraction and gel electrophoresis were performed $6 \mathrm{hr}$ after STS treatment $(1 \mu \mathrm{M})$.

1998). We found that, at $1 \mu \mathrm{M}$ of STS, few DNA fragments at nucleosomal levels were generated within $6 \mathrm{hr}$ of drug treatment. However, cotransfection of rat CAD/DFF40 and ICAD cDNAs, but not CAD/DFF40 or ICAD alone, greatly enhanced STSinduced internucleosomal DNA fragmentation. These results are consistent with the notion that ICAD is an essential chaperone for CAD/DFF40 to acquire its soluble state in the cell and to then be activated by caspases (Sakahira et al., 1999). We concluded 

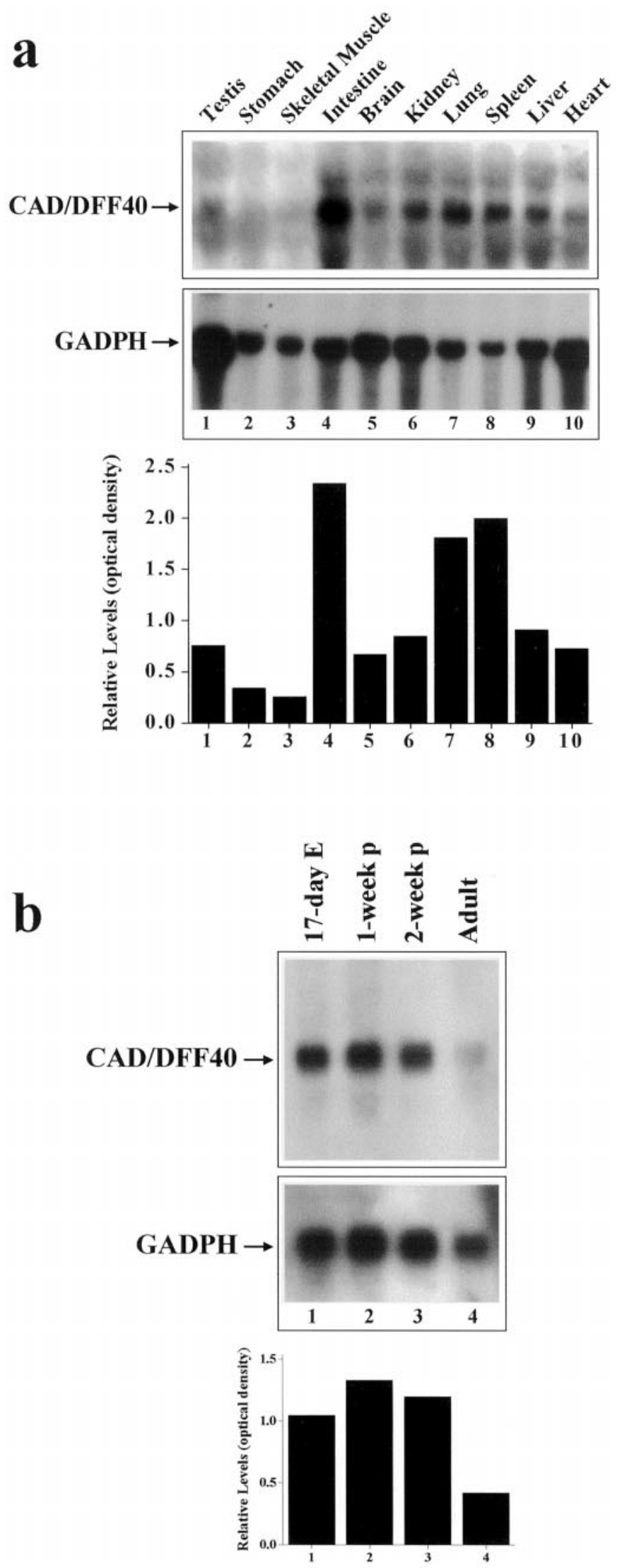

Figure 2. Northern blot analysis of CAD/DFF40 mRNA in the rat. Total RNA was isolated from rat tissues and electrophoresed on a $1 \%$ agaroseformaldehyde gel (30 $\mu \mathrm{g}$ of RNA per lane). The only transcription species resulting from hybridizing with the CAD/DFF40 cDNA probe is $\sim 2.7 \mathrm{~kb}$. that the cloned rat brain cDNA encodes a functional caspaseactivated DNase.

\section{CAD/DFF40 is widely distributed and developmentally regulated in the brain}

The expression of CAD/DFF40 mRNA was examined in various organ tissues in adult rats and in developing rat brains using Northern blots. CAD mRNA was detected at the highest level in the intestine; this was followed by the spleen, lung, kidney, liver, testis, heart, and brain (Fig. 2a). Low levels of CAD/DFF40 mRNA were found in the stomach and skeletal muscle. In the adult rat brain, no $\mathrm{CAD} / \mathrm{DFF} 40$ expression variation was detected in different brain regions tested (data not shown). In the cerebellum, which undergoes massive neuronal apoptosis during brain development, expression of CAD/DFF40 mRNA showed a marked difference between developing and adult rats (Fig. 2b). High levels of expression were detected in 17-d-old embryos and 1- and 2-week-old newborn rats, whereas the level was decreased $\sim 4.5$-fold in the adult rats.

\section{Evidence of CAD/DFF40 gene induction after ischemia}

To study the role of CAD/DFF40 in apoptotic DNA fragmentation in cerebral ischemia, we examined the expression of CAD/ DFF40 at both mRNA and protein levels in normal and ischemic brains, focusing on the hippocampus, in which neurons are particularly vulnerable to transient global ischemia. Using Northern blotting, we detected alterations in CAD/DFF40 mRNA expression in ischemic brains. CAD/DFF40 mRNA was present at very low level in the control nonischemic brain, but the level was increased at $8 \mathrm{hr}$ (2.37-fold), $24 \mathrm{hr}$ (2.64-fold), and $72 \mathrm{hr}$ (1.9-fold) after $15 \mathrm{~min}$ of ischemia (Fig. $3 a$ ). The cellular distribution of CAD/DFF40 mRNA was further examined using in situ hybridization in normal brains and in brains 4, 8, 24, and $72 \mathrm{hr}$ after ischemia ( $n=4$ per time point). Consistent with the results of Northern blots, very low levels of CAD/DFF40 mRNA were detected in the normal hippocampal formation. Eight hours after ischemia, increased CAD/DFF40 mRNA signals began to be detectable in the hippocampal CA1 sector (Fig. 3b). The signal was further elevated selectively in CA1 at 24 and $72 \mathrm{hr}$ after ischemia. Furthermore, examination of emulsion-coated sections (72 $\mathrm{hr}$ after ischemia) that were counterstained with terminal deoxynucleotidyl transferase-mediated biotinylated UTP nick end labeling (TUNEL) confirmed that many CA1 neurons that showed increased CAD/DFF40 gene expression contained DNA fragmentation (Fig. 3c).

\section{Evidence of CAD/DFF40 protein alterations after ischemia}

CAD/DFF40 immunoreactivity was readily detectable in normal nonischemic hippocampus using Western blotting. Western blots performed after subcellular fractionation revealed that CAD/ DFF40 protein was localized predominantly in the nucleus rather

$a$, Distribution of CAD/DFF40 mRNA in various adult rat tissues. $b$, Regulation of CAD/DFF40 mRNA expression in the cerebellum during development. 17-day E, Embryonic day 17; 1-week p, postnatal 1 week; 2 -week $p$, postnatal 2 weeks. In all Northern blot analyses, the same blot was hybridized with the GADPH probe to serve as a control for sample loading. The graphs under the blots illustrate the relative levels of CAD/ DFF40 mRNA expression in tissues, determined by optical density measurement on autoradiograms from two independent experiments. All densitometric values for $\mathrm{CAD} / \mathrm{DFF} 40$ were normalized to that for GAPDH determined on the same lane. 


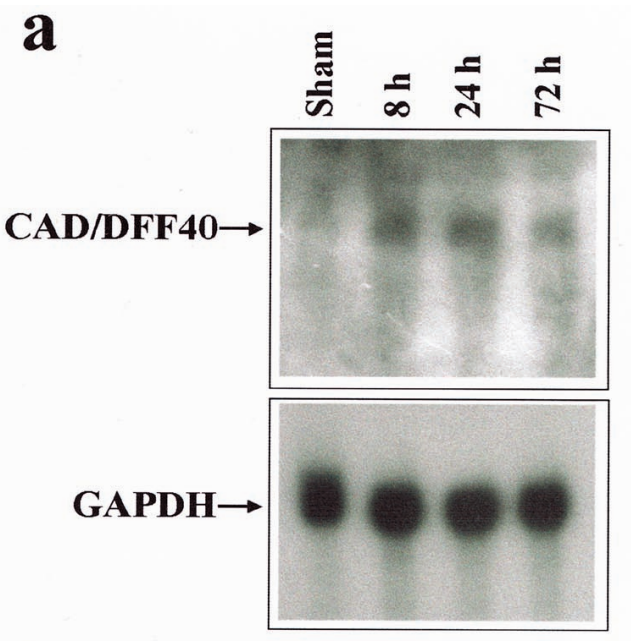

b

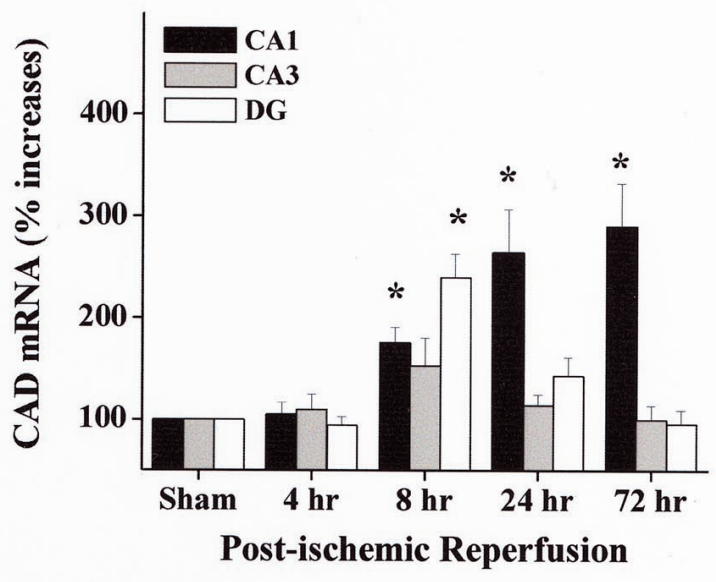

c

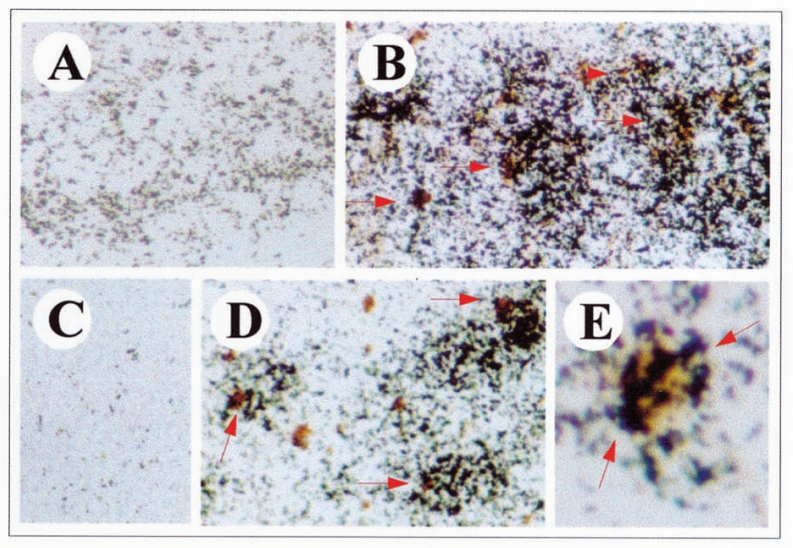

Figure 3. Alterations of CAD/DFF40 mRNA expression after cerebral ischemia. $a$, Top, Northern blot analysis of CAD/DFF40 mRNA in the hippocampus after sham operation or 8,24 , or $72 \mathrm{hr}$ after ischemia. Total RNA was isolated from the hippocampi (three brains per time point) and electrophoresed through a $1 \%$ agarose-formaldehyde gel (30 $\mu \mathrm{g}$ of RNA per lane). Bottom, the same blot hybridized with the GAPDH probe serves as the sample-loading control. $b$, In situ hybridization analysis of CAD/DFF40 mRNA expression in the hippocampus after ischemia or sham operation. The graph illustrates the relative CAD/DFF40 mRNA changes in the hippocampal CA1 sector, CA3 sector, and dentate gyrus $(D G)$ at $4,8,24$, and $72 \mathrm{hr}$ after ischemia versus sham controls $(n=4$ per time point), determined by optical density measurement on autoradiograms. Data are mean \pm SEM and represent percentage changes in ischemic brains versus sham controls. ${ }^{*} p<0.05$ versus sham controls than in the cytosol (Fig. 4a), consistent with the recent observations in several other cell types (Chen et al., 2000). Immunoprecipitation followed by Western blotting demonstrated that the $\mathrm{CAD} / \mathrm{ICAD}$ heterodimeric complex was also present in the nuclear, but not in the cytosolic, fraction in normal brain cells (Fig. $4 b)$. At 24 and $72 \mathrm{hr}$ after global ischemia, nuclear CAD/DFF40 immunoreactivity was significantly increased in the hippocampal CA1 region (Fig. 4c); however, these changes were not detected in hippocampal tissues containing CA3 and dentate gyrus only (data not shown).

The cellular distribution of CAD/DFF40 immunoreactivity in the hippocampus was examined using immunohistochemistry. In contrast to the results of Western blotting, normal nonischemic hippocampal neurons contained extremely weak or no CAD/ DFF40 immunoreactivity. Despite the increased levels of CAD/ DFF40 immunoreactivity at 8 and $24 \mathrm{hr}$ after ischemia shown by Western blots, such changes were not detected at the cellular level by immunohistochemistry. At $72 \mathrm{hr}$ after ischemia, however, a markedly increased CAD/DFF40 immunoreactivity with nuclear localization was detected in most CA1 neurons (Fig. $4 d$ ). Doublelabel immunohistochemistry showed a colocalization of increased CAD/DFF40 and caspase-3 immunofluorescence in the nucleus. At this time point, the majority of CA1 neurons $(>90 \%)$ showed pyknotic changes (shrinkage of the cell body and condensation of the nucleus) and in situ DNA fragmentation (TUNEL staining).

Normally, CAD/DFF40 is present in the cells in its inactive state by forming a heterodimeric complex with ICAD (Liu et al., 1997; Sakahira et al., 1998; Chen et al., 2000). Cleavage of ICAD by caspase- 3 at the two specific recognition sites (residues 114 and 224 ) is required for the release of ICAD from the complex and subsequent activation of CAD/DFF40. Thus, detection of the specific cleavage products of ICAD is an indirect but specific marker for CAD/DFF40 activation (Chen et al., 2000). Accordingly, we examined the integrity of ICAD in nuclear and cytosolic protein extracts prepared from hippocampal CA1 region, respectively. The antibody was raised against the amino acid sequence (WKNVARQLKEDLSSI) present in both intact and the deduced larger cleavage product $(16.5 \mathrm{kDa})$ of ICAD. Western blots revealed that ICAD was present in both cytosolic and nuclear fractions. The cleavage product of ICAD began to be detectable in the cytosol at $8 \mathrm{hr}$ after ischemia, and the amount of cleavage product was further increased at 24 and $72 \mathrm{hr}$ after ischemia (Fig. $5 a, b)$. In contrast, cleavage of nuclear ICAD was not detected until $72 \mathrm{hr}$ after ischemia. Immunoblotting of the nuclear protein extracts also revealed that caspase-3, exclusively the active p17 subunit, was present in the nucleus at $72 \mathrm{hr}$, but not in any other points, after ischemia, whereas activation of caspase- 3 began to be detectable in the cytosolic fraction as early as $8 \mathrm{hr}$ after ischemia (Fig. 5a,b). Thus, the time course for cytosolic ICAD cleavage in the ischemic hippocampus was parallel to that of caspase-3 activation, whereas cleavage of nuclear ICAD coincided with the nuclear translocation of active caspase-3.

The above results suggest that nuclear translocation of the active form of caspase-3 (p17) may be required for the activation of CAD/DFF40 in the nucleus after ischemia. To test this hy-

\section{$\leftarrow$}

(ANOVA and post hoc Scheffe's tests). $c$, Representative emulsion-coated sections counterstained with TUNEL from a brain $72 \mathrm{hr}$ after ischemia $(B, D, E)$ and a sham control brain $(A, C)$. Note that increased silver grains localize to TUNEL-positive (yellow stains) CA1 pyramidal neurons $(B)$ and neurons in the caudate putamen $(D, E)$. Magnification, $400 \times$. 

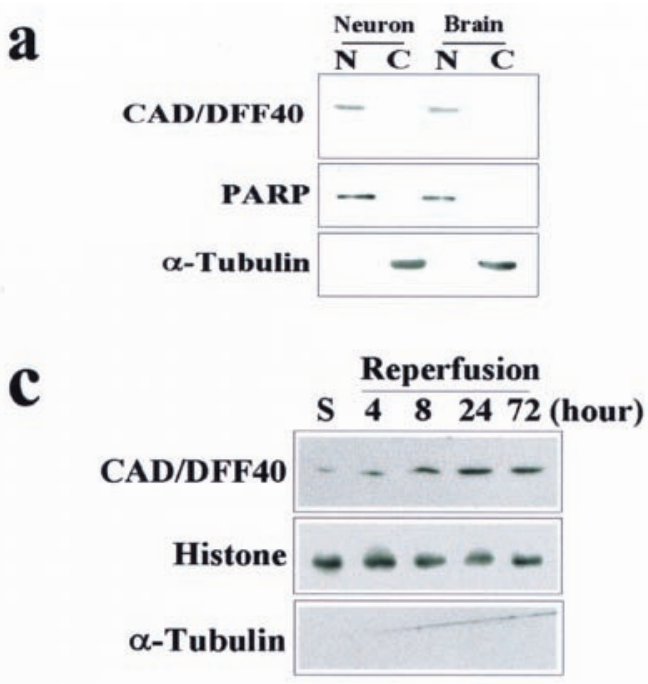

d
Caspase-3 Cresyl Violet
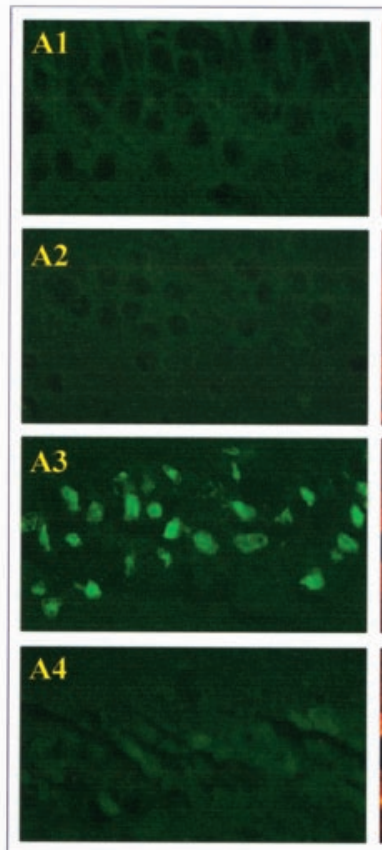

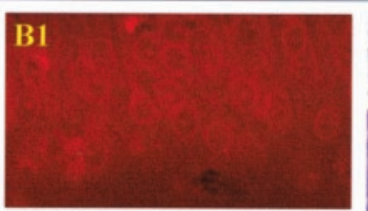

B2
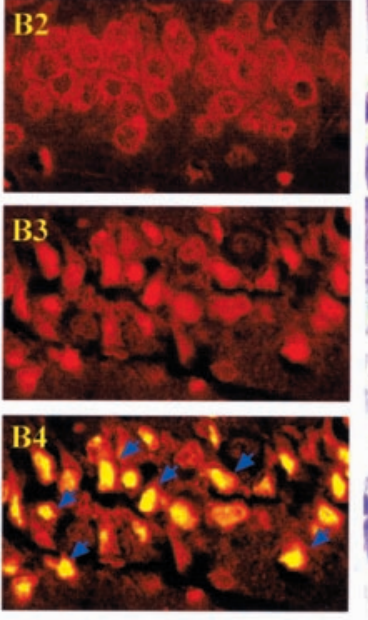

b

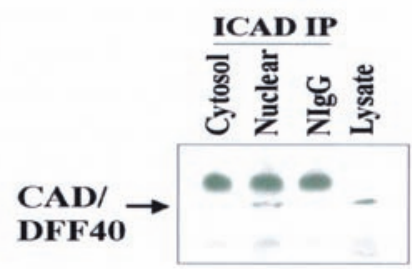

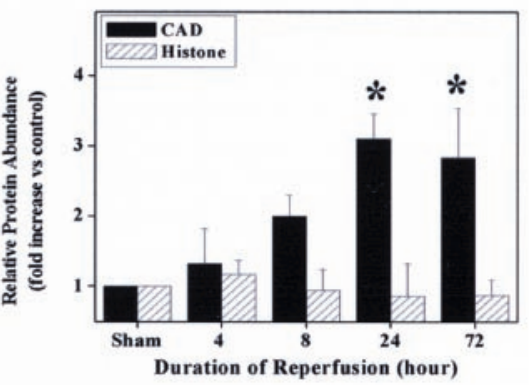

TUNEL

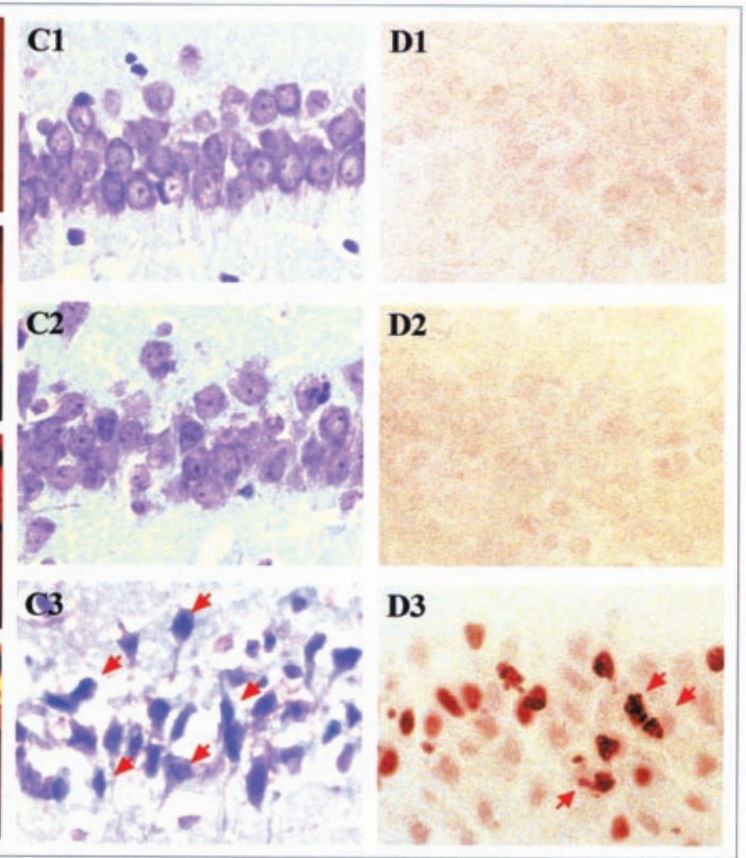

Figure 4. Alterations in CAD/DFF40 protein expression after cerebral ischemia. $a$, Western blot analysis of CAD/DFF40 in the nuclear $(N)$ and cytosolic $(C)$ fractions prepared from normal brain cells (Brain) and primary cortical neuron cultures (Neuron). Immunoblots of PARP (a nuclear marker) and $\alpha$-tubulin (a cytosolic marker) serve to confirm the validity of the subcellular fractionation procedure. $b$, Immunoprecipitation (IP) of the CAD-ICAD complex in normal rat brain cell extracts using anti-ICAD antibody followed by immunoblotting using the anti-CAD/DFF40 antibody. The complex is detected in the nuclear but not in the cytosolic fraction. Normal rabbit $\operatorname{IgG}(\mathrm{NIgG})$ and brain protein extracts (Lysate) serve as negative and positive controls, respectively. $c$, Representative Western blots (left panel) show increases in CAD/DFF40 immunoreactivity in the nuclear fraction after ischemia. Control Western blots show that the purified protein fraction is enriched in the nuclear protein histone but does not contain the cytosolic protein $\alpha$-tubulin. Shown in the right panel are semiquantitative results of relative abundance of CAD/DFF40 and histone immunoreactivity in the nuclear fraction after ischemia, as determined using densitometric measurement on three individual Western blots performed using three different sets of brain samples. Data are mean \pm SEM and represent fold changes in ischemic brains versus sham controls. ${ }^{*} p<0.05$ versus sham controls (ANOVA and post hoc Scheffe's tests). $d$, Immunohistochemical staining of CAD/DFF40 (A1-A4) and caspase-3 (B1-B3) in the hippocampal CA1 sector after ischemia. Compared with that in the control brain $(A 1)$ and $24 \mathrm{hr}$ after ischemia $(A 2), \mathrm{CAD} / \mathrm{DFF} 40$ immunofluorescence is markedly increased in the nucleus of CA1 neurons at $72 \mathrm{hr}$ after ischemia $(A 3)$. Omission of the primary antibody from immunostaining results in no positive signals $(A 4)$. Double-label in the section obtained $72 \mathrm{hr}$ after ischemia shows the colocalization of increased CAD/DFF40 and caspase-3 immunofluorescence in CA1 neurons (B4, blue arrows). Note that caspase-3 immunofluorescence is increased at both $24 \mathrm{hr}(B 2)$ and $72 \mathrm{hr}$ (B3) after ischemia, however; only at 72 $\mathrm{hr}$ after ischemia does caspase-3 show a nuclear localization (B3). In keeping with delayed cell death in this model, cresyl violet staining demonstrates that CA1 neurons show normal morphology in control brain $(C 1)$ and in the brain $24 \mathrm{hr}$ after ischemia $(C 2)$ but show pyknotic changes in the brain 72 $\mathrm{hr}$ after ischemia (C3, red arrows). As determined using TUNEL staining, DNA fragmentation is not detected in control brain (D1) or at $24 \mathrm{hr}$ after ischemia (D2), but it occurs in a majority of CA1 neurons at $72 \mathrm{hr}$ after ischemia (D3). Note that TUNEL-positive neurons show a condensed, shrunken, or fragmented nucleus $(D 3$, red arrows). 

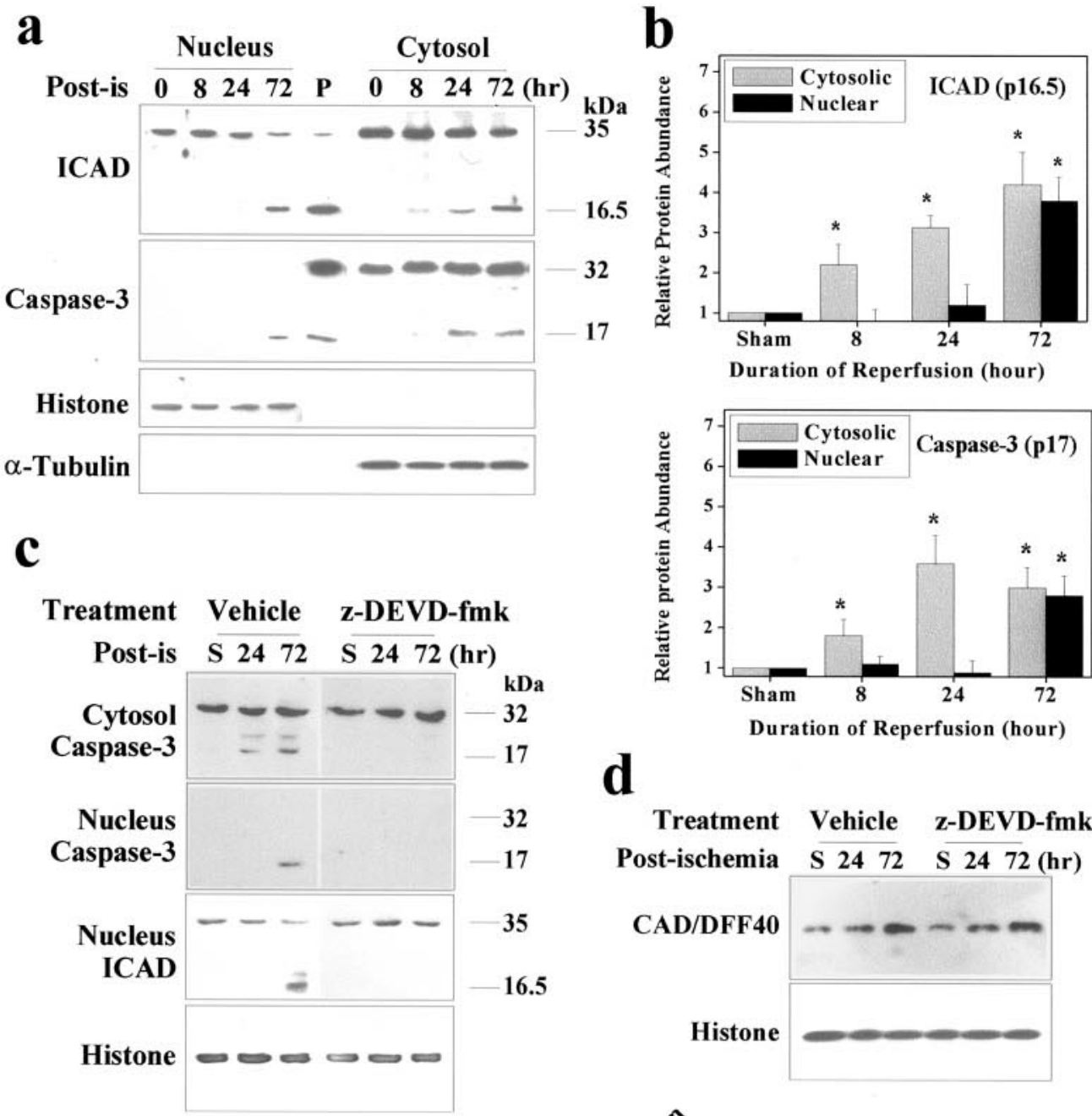

e

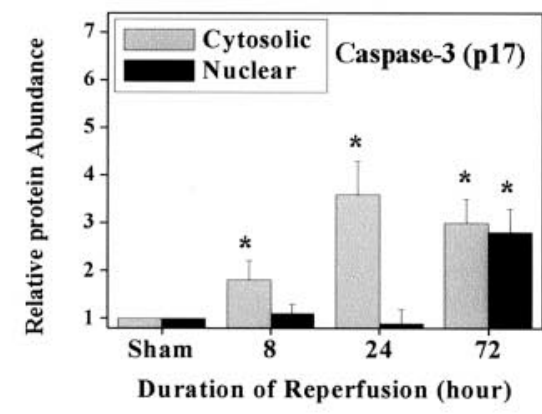

d

Treatment Vehicle z-DEVD-fmk

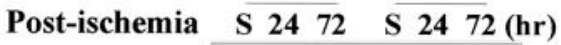

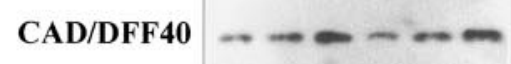

Histone

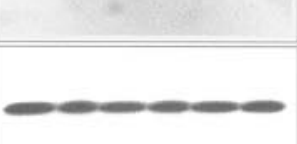

Treatment

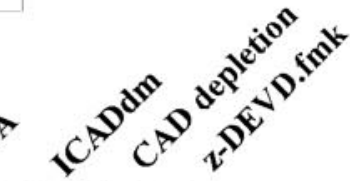

$\begin{array}{lllllllllll}\text { Reperfusion } S & 8 & 24 & 72 & 72 & 72 & 72 & 72 & \overline{72} & \overline{72} & \text { (hour) }\end{array}$

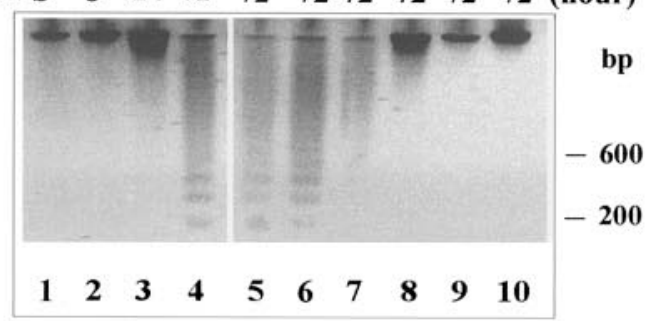

rat ICAD $\mathrm{m} \quad \mathrm{m} \quad \mathrm{w}$ w

Caspase-3 - + - + kDa

600

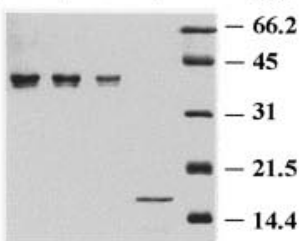

f

Post-ischemic

reperfusion

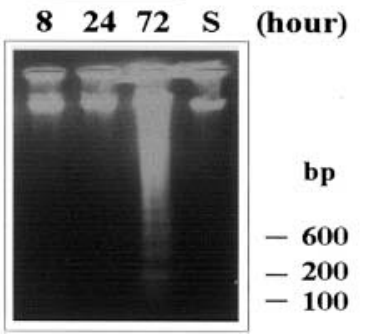


pothesis, brains receiving intracerebral ventricular infusion of $z$-DEVD-fmk were processed for Western blot analysis at 24 and $72 \mathrm{hr}$ after ischemia. $z$-DEVD-fmk, at the optimal dose $(4.5 \mu \mathrm{g})$ that prevented CA1 cell death in this model (Chen et al., 1998a), completely blocked cytosolic activation and nuclear translocation of caspase-3 and also prevented ICAD cleavage in the nucleus (Fig. 5c). However, $z$-DEVD-fmk failed to prevent the increases in the levels of CAD/DFF40 immunoreactivity in the nucleus after ischemia, as determined using Western blot analysis (Fig. $5 d$ ). These results suggest that increased nuclear accumulation of CAD/DFF40 after ischemia is independent of caspase-3 activity, but the cleavage of nuclear ICAD and, presumably, the activation of CAD/DFF40 is a caspase-3-dependent process. The delayed nuclear translocation of caspase-3 may explain the discrepancies between Western blots and immunohistochemistry in the time course of increased CAD/DFF40 immunoreactivity in CA1 neurons.

\section{Detection of induced CAD/DFF40 activity after in vivo ischemia}

Nuclear translocation of active caspase-3 and cleavage of ICAD in CA1 neurons strongly suggest that endogenous CAD/DFF40 is activated after ischemia. To directly address this hypothesis, we isolated nuclear protein from the hippocampal CA1 sector of control nonischemic brains or brains at 24 or $72 \mathrm{hr}$ after ischemia ( $n=6$ per condition, 2 brains per sample) and performed DNA fragmentation assays. Nuclear extracts from the $72 \mathrm{hr}$ group but not the 8 or $24 \mathrm{hr}$ or control groups induced internucleosomal fragmentation in genomic DNA of normal brain cells (Fig. 5e). Thus, the temporal profile of induced CAD/DFF40 activity was consistent with that of the induction of internucleosomal fragmentation of endogenous DNA in CA1 after ischemia (Fig. 5f). Moreover, this induced DNase activity was completely blocked by adding the caspase-resistant ICAD fusion protein to the reaction mixture but was not affected by the nonspecific endonuclease inhibitor aurintricarboxylic acid (ATA). This DNase was undetectable in nuclear extracts prepared from brains that received $z$-DEVD-fmk inf usion. Furthermore, immunodepletion of CAD/ DFF40 in the nuclear extracts also abolished the DNA fragmentation-inducing activity (Fig. 5e).

\section{Detection of induced CAD/DFF40 activity after in vitro ischemia}

To determine whether the induced CAD/DFF40 activity is a unique phenomenon in global ischemia or represents a common mechanism for apoptotic DNA degradation in other ischemiarelevant models, we examined CAD/DFF40 activity in the in vitro model of ischemia in primary neuronal cultures induced by OGD. This model was modified from that previously reported (Gwag et al., 1995), in which the apoptotic component of cell death can be unmasked by blocking the NMDA receptor. We found that, in the presence of low concentrations of the NMDA receptor antagonist MK801 (1-10 nM), OGD markedly induced apoptosis ( 35-50\% of total cells) in neuronal cultures (Fig. $6 a-c$ ) via a caspase-3mediated mechanism (G. Cao, W. Pei, and J. Chen, unpublished data). In the present study, we subjected the cortical cultures to 90 min of OGD in the presence of MK801 (1 nM) and collected nuclear proteins at $0,4,12$, or $24 \mathrm{hr}$ after OGD. Western blot analysis revealed that nuclear ICAD was cleaved at 12 and $24 \mathrm{hr}$ after OGD, coinciding with the time course of nuclear translocation of active caspase- 3 and the proteolytic cleavage of poly (ADP-ribose) polymerase (PARP), another nuclear substrate for caspase-3 (Fig. $6 d$ ). Inconsistent with the degradation of nuclear ICAD, a markedly induced CAD/DFF40 activity that resulted in apoptotic DNA fragmentation in isolated genomic DNA was detected in nuclear extracts of neurons at 12 and $24 \mathrm{hr}$ after OGD (Fig. 6e).

To determine whether the induced CAD/DFF40 activity in neurons results in nuclear morphological changes in addition to its DNA-degradation effect, the cell-free apoptosis assay using nuclear extracts was performed. As shown in Figure $6 f$, nuclear extracts from neurons at $12 \mathrm{hr}(B)$ or $24 \mathrm{hr}(C)$ after OGD, but not from normal control neurons $(A)$, induced extensive chromatin condensation and fragmentation in isolated normal neuronal nuclei. The addition of purified ICAD $_{\mathrm{dm}}$ fusion protein $(1 \mu \mathrm{g} / \mathrm{ml})$ to the reaction mixture completely prevented nuclear fragmentation but failed to reverse the shrinkage and condensation of the nuclei $(D)$. These results suggest that the induced CAD/DFF40 activity in neurons is responsible for some, but not all, nuclear morphological changes in apoptosis.

\section{$\leftarrow$}

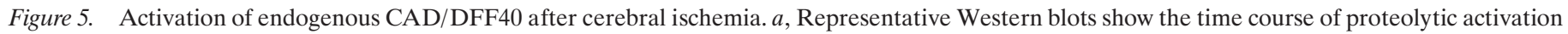

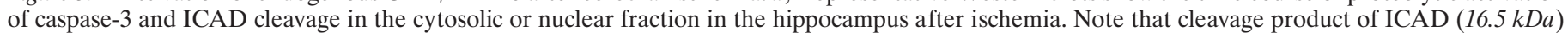

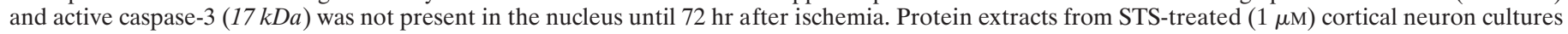

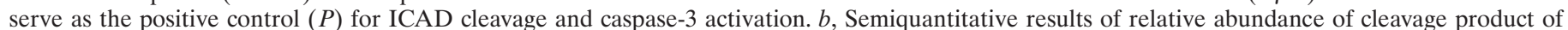

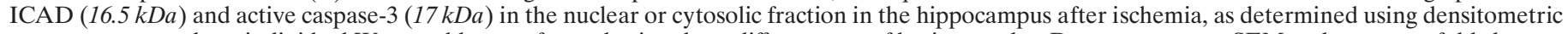

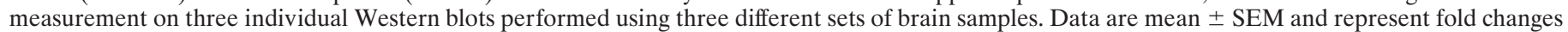

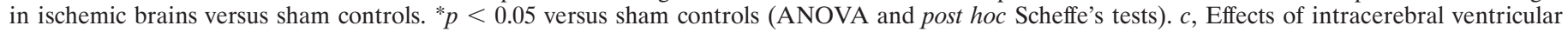

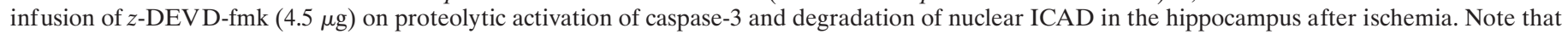

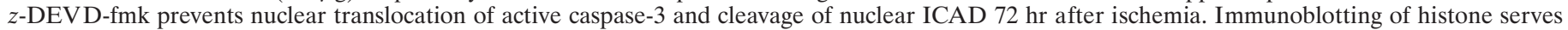

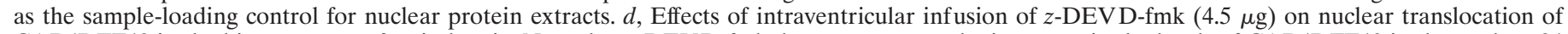

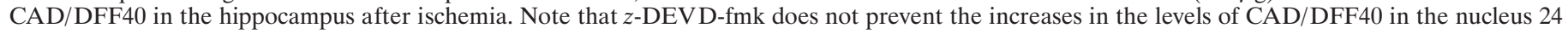

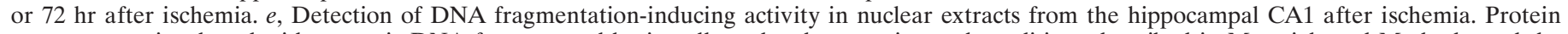

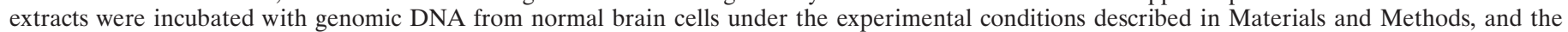

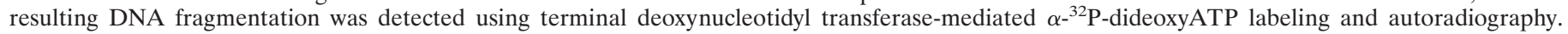

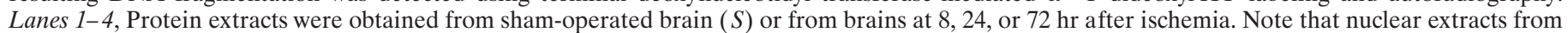

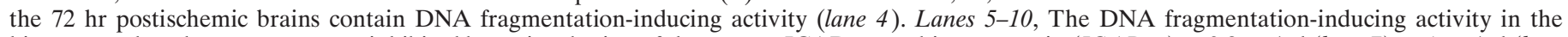

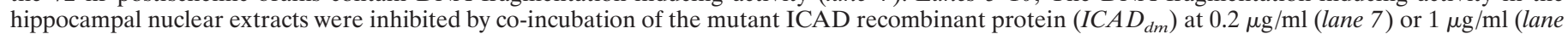

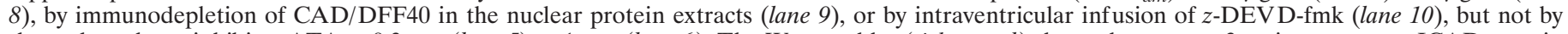

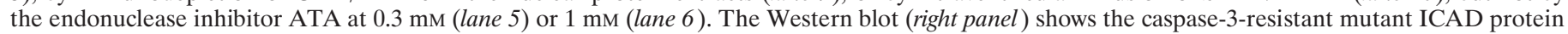

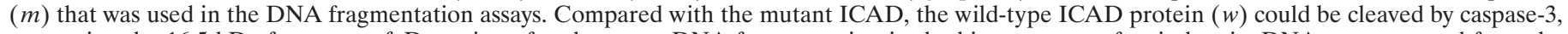

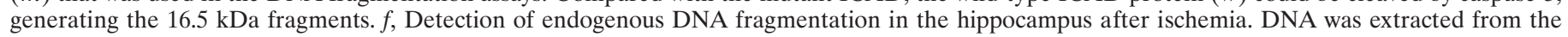

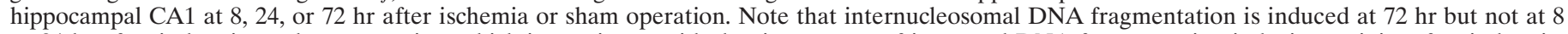

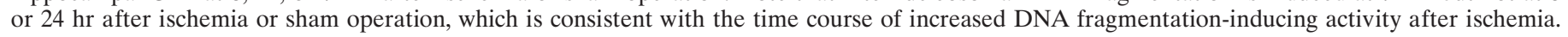


a

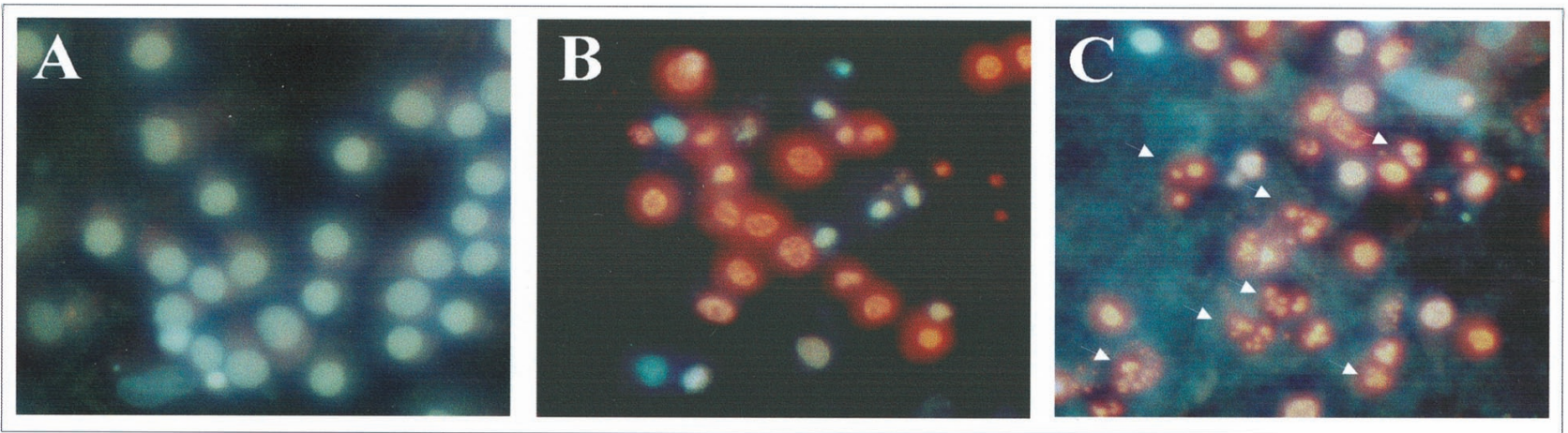

b

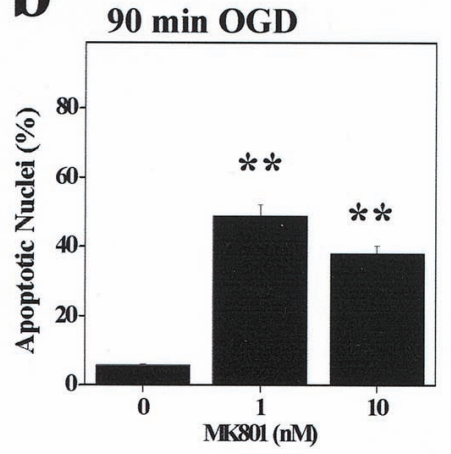

c

OGD - ++++

$\operatorname{MK801(nM)~-~} \quad 1101$

z-DEVD.fmk - - - + +

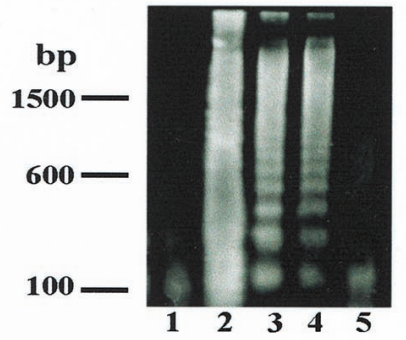

d

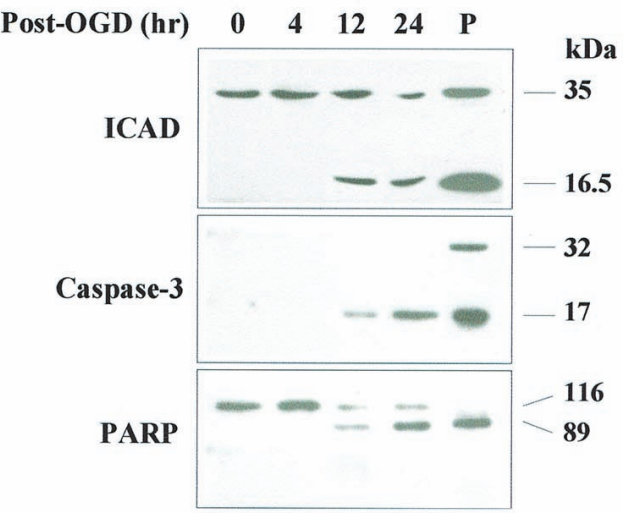

$\mathbf{e}$
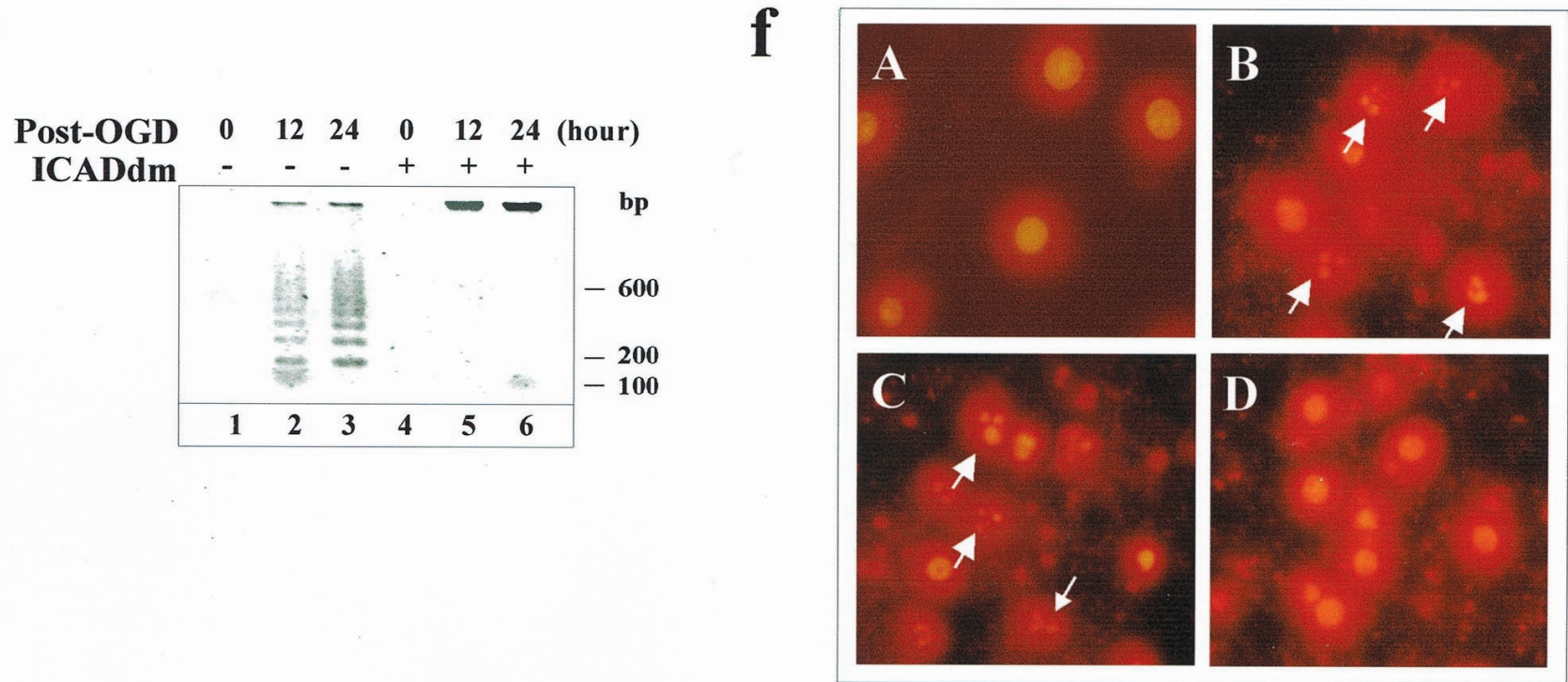

Figure 6. Activation of endogenous CAD/DFF40 in primary cortical cultures. $a$, Oxygen and glucose deprivation $(O G D)$ induced apoptotic nuclear changes in neurons in the presence of low concentration of MK801 (1 nM). Nuclear morphology was evaluated using propidium iodine (red) and counterstaining with Hoechst 33258 (blue) at $24 \mathrm{hr}$ after 90 min of OGD. $A$, Nuclei of normal neurons; $B$, nuclei of OGD-treated neurons in the absence of MK801; $C$, nuclei of OGD-treated neurons in the presence of MK801. Arrowheads point to nuclei that show characteristic changes of apoptosis. $b$, Quantitative results show that, in the presence of MK801, OGD significantly increased apoptosis in neuronal cultures. Apoptosis was quantified 24 hr after OGD by counting nuclei that showed chromatin condensation and fragmentation after propidium iodine DNA-staining. Data are mean \pm SEM, and each data point represents cell counts of at least 3000 neurons from two independent experiments. $* *<<0.01$ versus sham controls $($ ANOVA and post hoc Scheffe's tests). c, DNA ladder. Lane 1, Normal neurons; lane 2, $24 \mathrm{hr}$ after $90 \mathrm{~min}$ of OGD, without MK801; lanes 3-4, 24 hr after OGD, in the presence of 1 and $10 \mathrm{~nm} \mathrm{MK801,} \mathrm{respectively;} \mathrm{lane} \mathrm{5,} 24 \mathrm{hr}$ after OGD, in the presence of both MK801 (1 nM) and $z$-DEVD-fmk (100 $\mu \mathrm{M})$. Note that, in the presence of MK801, OGD induces caspase-dependent internucleosomal DNA fragmentation. $d$, Western blots show the time course of nuclear translocation of active caspase-3 $(17 \mathrm{kDa})$ and proteolytic cleavage of ICAD and PARP (another marker of caspase-3 activation) in the nucleus after 90 min of OGD (in the presence of $1 \mathrm{~nm}$ MK801). Nuclear protein was extracted from neurons at 0, 4, 12, or $24 \mathrm{hr}$ after OGD. Cell lysates from STS-treated (1 $\mu \mathrm{M})$ neurons serve as the positive control $(P)$. e, Detection of DNA fragmentation-inducing activity in nuclear extracts from neurons at 12 or 24 hr $($ lanes 2-3) after $90 \mathrm{~min}$ of OGD (with the addition of $1 \mathrm{~nm}$ MK801). Protein extracts were incubated with genomic DNA from normal (Figure legend continues) 


\section{DISCUSSION}

Neuronal apoptosis resulting from cerebral ischemia and related brain insults may involve the induction and activation of a host of gene products (for review, see Lipton, 1999; Sharp et al., 2000; Graham and Chen, 2001). Among the execution molecules in the cascade of neuronal apoptosis, caspase-3 appears to play a central role (Hara et al., 1997; Yakovlev et al., 1997; Chen et al., 1998a; Namura et al., 1998). Caspase-3, when proteolytically activated, cleaves several specific cellular proteins, leading to the irreversible morphological and biochemical changes of apoptosis (Cohen, 1997; Thornberry and Lazebnik, 1998). In the present study, we demonstrate that CAD/DFF40, a caspase-3-activated DNAdegradation enzyme, is induced in neurons after transient global cerebral ischemia. CAD/DFF40 mRNA and protein were increased in the hippocampal CA1 neurons, which are selectively vulnerable to ischemic injury. The DNase activity of CAD/ DFF40 was markedly induced in the nucleus of ischemic CA1 neurons and in neuronal cultures under ischemia-related conditions, and the temporal profile of this induction coincided with nuclear translocation of active caspase-3 and the induction of DNA fragmentation. Furthermore, the induced nuclear CAD/ DFF40 activity was blocked by inhibition of caspase-3-like protease activity in ischemic CA1 neurons or forced overexpression of the endogenous CAD/DFF40 inhibitor ICAD in neuronal cultures. These results strongly support the hypothesis that caspase-3, via activating nuclear CAD/DFF40, mediates apoptotic DNA fragmentation after transient cerebral ischemia and in neuronal cultures under ischemia-like conditions.

It has been suggested that CAD/DFF40-induced DNA fragmentation may constitute a common molecular pathway for irreversible DNA degradation during both physiological and pathological apoptosis (Mukae et al., 1998). The CAD/DFF40 gene is highly conserved across species, because it has so far been identified in human (Mukae et al., 1998), mouse (Enari et al., 1998), Drosophila melanogaster (Mukae et al., 2000), and rat (this study). Sequence analysis revealed that the deduced amino acid sequence of CAD/DFF40 shares high homology among human, mouse, and rat (Fig. 1). The 80 amino acid $\mathrm{N}$ terminus of CAD/DFF40, which shows nearly $50 \%$ of identity to ICAD, is believed to be essential for CAD/DFF40 to form a heterodimeric complex with ICAD (Mukae et al., 1998); the C terminus, consisting of a stretch of repetitive glutamine, proline, arginine, and lysine residues, constitutes the nuclear translocation segment. When examined in adult rat, CAD/DFF40 transcripts are found to be wildly distributed in various tissues. The intestine, an organ that normally commits a high rate of cell turnover by apoptosis, shows the highest level of CAD/DFF40 expression, whereas the brain and heart, which consist of mainly long-lived cells, have lower levels of CAD/DFF40 (Fig. 2). Furthermore, the expression of CAD/ DFF40 in the brain is highly regulated during development; it shows very high levels in 1 - to 2 -week-old postnatal young rats, but is downregulated throughout adulthood. These results are consistent with previous observations that the level of constitutive
CAD/DFF40 expression is proportional to the ability of cells to develop apoptosis and DNA fragmentation (Mukae et al., 1998).

The data presented here demonstrate that the CAD/DFF40 gene is induced and the CAD/DFF40 protein is activated selectively in hippocampal neurons that undergo DNA fragmentation after global ischemia. Beginning at $8 \mathrm{hr}$ after ischemia, expression of CAD/DFF40 mRNA was persistently increased (at least $72 \mathrm{hr}$ ) in the selectively vulnerable CA1 neurons destined to develop internucleosomal DNA fragmentation (Fig. 3). This pattern of expression strikingly resembles that of proapoptotic genes caspase-3 and Bax studied in similar models of global ischemia (Krajewski et al., 1995; Chen et al., 1996, 1998a; Ni et al., 1998). Consistent with the time course of mRNA expression, upregulation of CAD/DFF40 protein in CA1 neurons, with a nuclear localization, at 8-72 $\mathrm{hr}$ after ischemia was confirmed by Western blot analysis. Somewhat surprisingly, immunohistochemistry failed to detect the increase in CAD/DFF40 immunoreactivity in CA1 neurons until $72 \mathrm{hr}$ after ischemia (Fig. 4). This discrepancy cannot be explained with certainty on the basis of the immunostaining experiments alone. However, because this delayed induction of CAD/DFF immunoreactivity coincided with the activation of nuclear CAD/DFF40, shown by detection of both ICAD cleavage and DNA fragmentation-inducing activity in nuclear extracts (Fig. 5), we suggest that the enhanced CAD/DFF40 immunoreactivity detected by immunohistochemistry in CA1 neurons may result from the increased active form of CAD/ DFF40 (free of ICAD binding). It is possible that the heterodimeric binding of ICAD to CAD/DFF40 may shield the antigen for immunohistochemical detection. Hence, the breakdown and relief of ICAD from the complex may enable the antigen to be accessible.

In line with the gene expression data, an induced CAD/DFF40 activity for DNA degradation was detected in nuclear extracts prepared from CA1 neurons $72 \mathrm{hr}$ after global ischemia (Fig. 5). The induced CAD/DFF40 activity was also detectable in neuronal cultures under ischemia-like conditions (Fig. 6), suggesting that the activation of $\mathrm{CAD} / \mathrm{DFF} 40$ may represent a common mechanism for ischemic apoptotic DNA degradation. Several lines of evidence support the specificity of the CAD/DFF40 activity detected in this study in both in vivo and in vitro models (Figs. 5, 6). First, the induction of the DNase activity after ischemia was associated with caspase-3-mediated proteolytic cleavage of ICAD. Second, the DNA fragmentation-inducing activity was completely blocked by the caspase-resistant ICAD fusion protein, but not by the nonspecific DNA endonuclease inhibitor ATA. Third, immunodepletion of CAD/DFF40 in the nuclear extracts abolished the DNA fragmentation-inducing activity. On the basis of the results, a functional role of the induced CAD/DFF40 activity after ischemia can be speculated. The activated CAD/DFF40 is responsible for the DNA fragmentation at the nucleosomal junctions in ischemic neurons, and it is also likely responsible for the late stage apoptotic nuclear changes such as nuclear fragmentation (Fig. $6 f$ ). However, it should be pointed

$\leftarrow$

neurons, and the resulting DNA fragmentation was detected using terminal deoxynucleotidyl transferase-mediated $\alpha-{ }^{32} \mathrm{P}-$ dideoxyATP labeling and autoradiography. This induced DNase activity was inhibited by the addition of mutant ICAD $\left(I C A D_{d m}\right)$ recombinant protein $(1 \mu \mathrm{g} / \mathrm{ml})$ to the reaction mixture (lanes 5-6). $f$, Effect of induced CAD/DFF40 activity on nuclear morphology. Nuclear extracts from normal neurons $(A)$ or neurons at 12 hr $(B)$ or $24 \mathrm{hr}(C)$ after OGD were incubated with nuclei isolated from normal neurons under conditions described in Materials and Methods, and nuclear morphology was evaluated by propidium iodine staining. Nuclear extracts from OGD-treated neurons result in chromatin fragmentation in isolated nuclei; this activity was inhibited by the addition of $\operatorname{ICAD}_{\mathrm{dm}}(1 \mu \mathrm{g} / \mathrm{ml})$ to the reaction mixture $(D)$. 
out that CAD/DFF40 is not responsible for all apoptotic nuclear changes in neurons. Our recent studies demonstrated that inactivating CAD/DFF40 in PC12 cells prevented nuclear fragmentation but failed to inhibit chromatin condensation in response to apoptosis inducers (Chen et al., 2000). Hence, other factors must participate in the process of apoptotic nuclear degradation as well. Two candidate factors have recently been proposed: AIF (apoptosis-inducing factor), a molecule released from mitochondria during apoptosis, likely induces high molecular weight DNA fragmentation in the genome (Susin et al., 1999; Ferri and Kroemer, 2000; Vieira et al., 2000); and acinus, another caspase-3activated molecule, appears to be partially responsible for apoptotic chromatin condensation (Sahara et al., 1999). Further work is warranted to determine whether these factors function synergistically with CAD/DFF40 and lead to nuclear degradation in ischemic neurons.

Caspase- 3 is the predominant molecule that is responsible for the activation of CAD/DFF40 (Wolf et al., 1999). A novel and potentially important finding resulting from this study is that caspase-3 undergoes nuclear translocation in ischemic neurons (Figs. 5, 6). These results are not totally unexpected, however, given that at least three nuclear residential proteins, including PARP, DNA-PK, and ICAD, are found to be cleaved by caspase-3 in ischemic neurons (Chen et al., 1998a; Shackelford et al., 1999). Although the mechanism that enables caspase-3 to translocate into the nucleus is not known, this observation may have important mechanistic implications. The delayed appearance of caspase-3 in the nucleus may explain why the induction of CAD/DFF40 activity was delayed after global ischemia (72 hr), although an increase in nuclear CAD/DFF40 protein was detected much earlier $(8 \mathrm{hr})$. We further propose that the activation of CAD/DFF40 after ischemia is a nuclear event, rather than a cytosolic process as previously speculated (Enari et al., 1998). In strong support of this hypothesis, we found that in normal brain cells, the CAD/ICAD complex is predominantly localized in the nucleus and that there is clear evidence of caspase-3 cleavage of nuclear ICAD in ischemic neurons. Furthermore, in vivo inf usion of $z$-DEVD-fmk in ischemic brains prevented the induction of CAD/DFF40 activity but did not decrease the nuclear levels of CAD/DFF40 protein (Fig. 5). These results are inconsistent with the previous cytosol hypothesis, in which CAD/DFF40 is presumably cytosolic and it translocates from the cytosol to the nucleus on the release of ICAD from the complex (Enari et al., 1998). In the later scenario, one would expect that inhibition of caspase-3-like activity would block the translocation of CAD/ DFF40 and, consequently, decrease the level of CAD/DFF40 in the nucleus. Interestingly, it was recently shown that a GFP-CAD protein is localized in the nucleus instead of in the cytosol of transfected cells (Samejima and Earnshaw, 2000), implying that a caspase-3-mediated cleavage of ICAD is not a prerequisite for CAD/DFF40 to enter the nucleus.

In summary, the present study provides strong evidence that the CAD/DFF40 gene is induced and its protein product is activated in selectively vulnerable neurons after transient cerebral ischemia and in cultured neurons under ischemia-related conditions. The CAD/DFF40 protein is activated in the nucleus via a novel mechanism that requires the nuclear translocation of caspase-3. The data resulting from in vivo and in vitro studies thus establish that CAD/DFF40 is the endogenous endonuclease responsible for the internucleosomal DNA degradation and nuclear chromatin fragmentation in neurons after ischemia.

\section{REFERENCES}

Boulikas T (1993) Nuclear localization signals (NLS). Crit Rev Eukaryot Gene Expr 3:193-227.

Chen D, Stetler RA, Cao G, Pei W, O'Horo C, Yin XM, Chen J (2000) Characterization of the rat DNA fragmentation factor 35/Inhibitor of caspase-activated DNase (short form). The endogenous inhibitor of caspase-dependent DNA fragmentation in neuronal apoptosis. J Biol Chem 275:38508-38517.

Chen J, Zhu RL, Nakayama M, Kawaguchi K, Jin K, Stetler RA, Simon RP, Graham SH (1996) Expression of the apoptosis-effector gene, Bax, is up-regulated in vulnerable hippocampal CA1 neurons following global ischemia. J Neurochem 67:64-71.

Chen J, Graham SH, Nakayama M, Zhu RL, Jin K, Stetler RA, Simon RP (1997) Apoptosis repressor genes Bcl-2 and Bcl-x-long are expressed in the rat brain following global ischemia. J Cereb Blood Flow Metab 17:2-10.

Chen J, Nagayama T, Jin K, Stetler RA, Zhu RL, Graham SH, Simon RP (1998a) Induction of caspase-3-like protease may mediate delayed neuronal death in the hippocampus after transient cerebral ischemia. J Neurosci 18:4914-4928.

Chen J, Uchimura K, Stetler RA, Zhu RL, Nakayama M, Jin K, Graham SH, Simon RP (1998b) Transient global ischemia triggers expression of the DNA damage-inducible gene GADD45 in the rat brain. J Cereb Blood Flow Metab 18:646-657.

Clemens JA, Stephenson DT, Dixon EP, Smalstig EB, Mincy RE, Rash KS, Little SP (1997) Global cerebral ischemia activates nuclear factorkappa B prior to evidence of DNA fragmentation. Brain Res Mol Brain Res 48:187-196.

Cohen GM (1997) Caspases: the executioners of apoptosis. Biochem J 326:1-16.

Colbourne F, Sutherland GR, Auer RN (1999) Electron microscopic evidence against apoptosis as the mechanism of neuronal death in global ischemia. J Neurosci 19:4200-4210.

Dixon EP, Stephenson DT, Clemens JA, Little SP (1997) Bcl-Xshort is elevated following severe global ischemia in rat brains. Brain Res 776:222-229.

Enari M, Sakahira H, Yokoyama H, Okawa K, Iwamatsu A, Nagata S (1998) A caspase-activated DNase that degrades DNA during apoptosis, and its inhibitor ICAD. Nature [Erratum (1998) 393:396] 391:43-50.

Ferrand-Drake M, Wieloch T (1999) The time-course of DNA fragmentation in the choroid plexus and the CA1 region following transient global ischemia in the rat brain. The effect of intra-ischemic hypothermia. Neuroscience 93:537-549.

Ferri KF, Kroemer G (2000) Control of apoptotic DNA degradation. Nat Cell Biol 2:E63-64.

Gillardon F, Bottiger B, Schmitz B, Zimmermann M, Hossmann KA (1997) Activation of CPP-32 protease in hippocampal neurons following ischemia and epilepsy. Brain Res Mol Brain Res 50:16-22.

Gillardon F, Kiprianova I, Sandkuhler J, Hossmann KA, Spranger M (1999) Inhibition of caspases prevents cell death of hippocampal CA1 neurons, but not impairment of hippocampal long-term potentiation following global ischemia. Neuroscience 93:1219-1222.

Graham SH, Chen J (2001) Programmed cell death in cerebral ischemia. J Cereb Blood Flow Metab 21:99-109.

Gwag BJ, Lobner D, Koh JY, Wie MB, Choi DW (1995) Blockade of glutamate receptors unmasks neuronal apoptosis after oxygen-glucose deprivation in vitro. Neuroscience 68:615-619.

Hara H, Friedlander RM, Gagliardini V, Ayata C, Fink K, Huang Z, Shimizu-Sasamata M, Yuan J, Moskowitz MA (1997) Inhibition of interleukin 1beta converting enzyme family proteases reduces ischemic and excitotoxic neuronal damage. Proc Natl Acad Sci USA 94:2007-2012.

Herrmann M, Lorenz HM, Voll R, Grunke M, Woith W, Kalden JR (1994) A rapid and simple method for the isolation of apoptotic DNA fragments. Nucleic Acids Res 22:5506-5507.

Himi T, Ishizaki Y, Murota S (1998) A caspase inhibitor blocks ischaemia-induced delayed neuronal death in the gerbil. Eur J Neurosci 10:777-781.

Honkaniemi J, Massa SM, Breckinridge M, Sharp FR (1996) Global ischemia induces apoptosis-associated genes in hippocampus. Brain Res Mol Brain Res 42:79-88.

Kinoshita M, Tomimoto H, Kinoshita A, Kumar S, Noda M (1997) Up-regulation of the Nedd2 gene encoding an ICE/Ced-3-like cysteine protease in the gerbil brain after transient global ischemia. J Cereb Blood Flow Metab 17:507-514.

Kitagawa K, Matsumoto M, Tsujimoto Y, Ohtsuki T, Kuwabara K, Matsushita K, Yang G, Tanabe H, Martinou JC, Hori M, Yanagihara T (1998) Amelioration of hippocampal neuronal damage after global ischemia by neuronal overexpression of BCL-2 in transgenic mice. Stroke 29:2616-2621.

Krajewski S, Mai JK, Krajewska M, Sikorska M, Mossakowski MJ, Reed JC (1995) Upregulation of bax protein levels in neurons following cerebral ischemia. J Neurosci 15:6364-6376. 
Lipton P (1999) Ischemic cell death in brain neurons. Physiol Rev 79:1431-1568.

Liu X, Kim CN, Yang J, Jemmerson R, Wang X (1996) Induction of apoptotic program in cell-free extracts: requirement for dATP and cytochrome c. Cell 86:147-157.

Liu X, Zou H, Slaughter C, Wang X (1997) DFF, a heterodimeric protein that functions downstream of caspase-3 to trigger DNA fragmentation during apoptosis. Cell 89:175-184.

MacManus JP, Buchan AM, Hill IE, Rasquinha I, Preston E (1993) Global ischemia can cause DNA fragmentation indicative of apoptosis in rat brain. Neurosci Lett 164:89-92.

Mukae N, Enari M, Sakahira H, Fukuda Y, Inazawa J, Toh H, Nagata S (1998) Molecular cloning and characterization of human caspaseactivated DNase. Proc Natl Acad Sci USA 95:9123-9128.

Mukae N, Yokoyama H, Yokokura T, Sakoyama Y, Sakahira H, Nagata S (2000) Identification and developmental expression of inhibitor of caspase-activated DNase (ICAD) in Drosophila melanogaster. J Biol Chem 275:21402-21408.

Nagayama T, Sinor AD, Simon RP, Chen J, Graham SH, Jin K, Greenberg DA (1999) Cannabinoids and neuroprotection in global and focal cerebral ischemia and in neuronal cultures. J Neurosci 19:2987-2995.

Namura S, Zhu J, Fink K, Endres M, Srinivasan A, Tomaselli KJ, Yuan J, Moskowitz MA (1998) Activation and cleavage of caspase-3 in apoptosis induced by experimental cerebral ischemia. J Neurosci 18:3659-3668.

Ni B, Wu X, Su Y, Stephenson D, Smalstig EB, Clemens J, Paul SM (1998) Transient global forebrain ischemia induces a prolonged expression of the caspase- 3 mRNA in rat hippocampal CA1 pyramidal neurons. J Cereb Blood Flow Metab 18:248-256.

Nitatori T, Sato N, Waguri S, Karasawa Y, Araki H, Shibanai K, Kominami E, Uchiyama Y (1995) Delayed neuronal death in the CA1 pyramidal cell layer of the gerbil hippocampus following transient ischemia is apoptosis. J Neurosci 15:1001-1011.

Ouyang YB, Tan Y, Comb M, Liu CL, Martone ME, Siesjo BK, Hu BR (1999) Survival- and death-promoting events after transient cerebral ischemia: phosphorylation of $\mathrm{Akt}$, release of cytochrome $\mathrm{C}$ and activation of caspase-like proteases. J Cereb Blood Flow Metab 19:1126-1135.

Sahara S, Aoto M, Eguchi Y, Imamoto N, Yoneda Y, Tsujimoto Y (1999) Acinus is a caspase-3-activated protein required for apoptotic chromatin condensation. Nature 401:168-173.

Sakahira H, Enari M, Nagata S (1998) Cleavage of CAD inhibitor in CAD activation and DNA degradation during apoptosis. Nature 391:96-99.
Sakahira H, Enari M, Nagata S (1999) Functional differences of two forms of the inhibitor of caspase-activated DNase, ICAD-L, and ICAD-S. J Biol Chem 274:15740-15744.

Samejima K, Earnshaw WC (2000) Differential localization of ICAD-L and ICAD-S in cells due to removal of a C-terminal NLS from ICAD-L by alternative splicing. Exp Cell Res 255:314-320.

Shackelford DA, Tobaru T, Zhang S, Zivin JA (1999) Changes in expression of the DNA repair protein complex DNA-dependent protein kinase after ischemia and reperfusion. J Neurosci 19:4727-4738.

Sharp FR, Lu A, Tang Y, Millhorn DE (2000) Multiple molecular penumbras after focal cerebral ischemia. J Cereb Blood Flow Metab 20:1011-1032.

Susin SA, Lorenzo HK, Zamzami N, Marzo I, Snow BE, Brothers GM, Mangion J, Jacotot E, Costantini P, Loeffler M, Larochette N, Goodlett DR, Aebersold R, Siderovski DP, Penninger JM, Kroemer G (1999) Molecular characterization of mitochondrial apoptosis-inducing factor. Nature 397:441-446.

Thornberry NA, Lazebnik Y (1998) Caspases: enemies within. Science 281:1312-1316.

Vieira O, Escargueil-Blanc I, Jurgens G, Borner C, Almeida L, Salvayre R, Negre-Salvayre A (2000) Oxidized LDLs alter the activity of the ubiquitin-proteasome pathway: potential role in oxidized LDL-induced apoptosis. FASEB J 14:532-542.

Wolf BB, Schuler M, Echeverri F, Green DR (1999) Caspase-3 is the primary activator of apoptotic DNA fragmentation via DNA fragmentation factor-45/inhibitor of caspase-activated DNase inactivation. J Biol Chem 274:30651-30656.

Wood ER, Earnshaw WC (1990) Mitotic chromatin condensation in vitro using somatic cell extracts and nuclei with variable levels of endogenous topoisomerase II. J Cell Biol 111:2839-2850.

Xu D, Bureau Y, McIntyre DC, Nicholson DW, Liston P, Zhu Y, Fong WG, Crocker SJ, Korneluk RG, Robertson GS (1999) Attenuation of ischemia-induced cellular and behavioral deficits by $\mathrm{X}$ chromosomelinked inhibitor of apoptosis protein overexpression in the rat hippocampus. J Neurosci 19:5026-5033.

Yakovlev AG, Knoblach SM, Fan L, Fox GB, Goodnight R, Faden AI (1997) Activation of CPP32-like caspases contributes to neuronal apoptosis and neurological dysfunction after traumatic brain injury. J Neurosci 17:7415-7424.

Zhu Y, Culmsee C, Semkova I, Krieglstein J (1998) Stimulation of beta2-adrenoceptors inhibits apoptosis in rat brain after transient forebrain ischemia. J Cereb Blood Flow Metab 18:1032-1039. 